\title{
Tectono-magmatic evolution of the Hutti-Maski Greenstone Belt, India: Constrained using geochemical and geochronological data
}

\author{
A.J. Rogers ${ }^{\mathrm{a}, *}$, J. Kolb ${ }^{\text {a }}$, F.M. Meyer ${ }^{\mathrm{a}, 1}$, R.A. Armstrong ${ }^{\mathrm{b}}$ \\ a Institute of Mineralogy and Economic Geology, RWTH Aachen University, Germany \\ ${ }^{\mathrm{b}}$ Research School of Earth Science, The Australian National University, Canberra, Australia
}

Received 7 February 2006; received in revised form 21 March 2007; accepted 6 April 2007

\begin{abstract}
The Hutti-Maski Greenstone Belt (HMGB), situated in the eastern block of the Dharwar Craton, India is dominated by bimodal volcanics with a minimum magmatic age of $2586 \pm 59 \mathrm{Ma}$. Two phases of granitoid intruded into the belt, the syn-tectonic Kavital granitoid, homogeneous, medium-grained porphyritic granodiorite, with an intrusion age of $2543 \pm 9$ Ma, followed by the post-tectonic Yelagatti granitoid, heterogeneous, fine- to medium-grained granite to granodiorite. The extensively altered zircons from the Yelagatti granitoid have significant enrichments of $\mathrm{U}$, Th $(>1 \%)$ and common- $\mathrm{Pb}$ (up to $47 \%$ ). Only two of the analyses were reproducible, providing a minimum ${ }^{207} \mathrm{~Pb} /{ }^{206} \mathrm{~Pb}$ age of $2221 \pm 99 \mathrm{Ma}$, this may indicate an approximate magmatic age or more realistically a subsequent event. Felsic metavolcanic rocks contain cross-cutting veinlets, which formed during the Mesoproterozoic (ca. $1180 \mathrm{Ma}$ ), the final closure of the $\mathrm{Pb}$ system occurred between the Neoproterozoic and Ordovician, possibly related to the Pan-African orogeny. The tectono-magmatic evolution of the HMGB can be correlated with the collision between the eastern and western blocks of the Dharwar Craton subsequent to $2658 \mathrm{Ma}$ and the craton wide magmatism from 2613 to $2513 \mathrm{Ma}$. These events can be accounted for by combining uniformitarian and non-uniformitarian models.
\end{abstract}

(c) 2007 Elsevier Ltd. All rights reserved.

Keywords: Dharwar Craton; Hutti-Maski; Greenstone Belt; SHRIMP

\section{Introduction}

The Hutti-Maski Greenstone Belt (HMGB) is situated towards the northeastern corner of the Dharwar Craton, southern India (Fig. 1). It is composed of a supracrustal suite metamorphosed to amphibolite facies, which is tectonically juxtaposed to basement gneiss and intruded by two granitoids (Srikantia, 1995). It is currently of particular interest as it hosts India's largest gold mine (Hutti Gold Mines Co., Ltd.), however, the lithologies to the northeast of the craton have been poorly studied, hindering a correlation and an interpretation of the units with respect to the evolution of the craton as a whole.

\footnotetext{
${ }^{*}$ Corresponding author.

E-mail address: rogers@iml.rwth-aachen.de (A.J. Rogers).

${ }^{1}$ Tel.: +492418095774.
}

Structural, geochemical and geochronological data from in and around the Kolar Greenstone Belt have been used to constrain different models for the Archean tectonism. Plate tectonic models similar to Phanerozoic settings (uniformitarian model) have been proposed by Krogstad et al. (1989) and Chadwick et al. (2000), suggesting that the Kolar Greenstone Belt today represents a late Archean suture zone, where two crustal segments amalgamated between 2530 and $2420 \mathrm{Ma}$, along a N-S trending shear zone during $\mathrm{E}-\mathrm{W}$ oblique convergence, which probably correlates with the HMGB $300 \mathrm{~km}$ to the north (Manikyamba et al., 2004). In contrast, Jayananda et al. (2000; non-uniformitarian model) distinguished four magmatic suites in a section from the east of the Kolar Greenstone Belt to the Closepet Granite in the west. They interpret this independent magmatic evolution as a result of a plume centered below the 


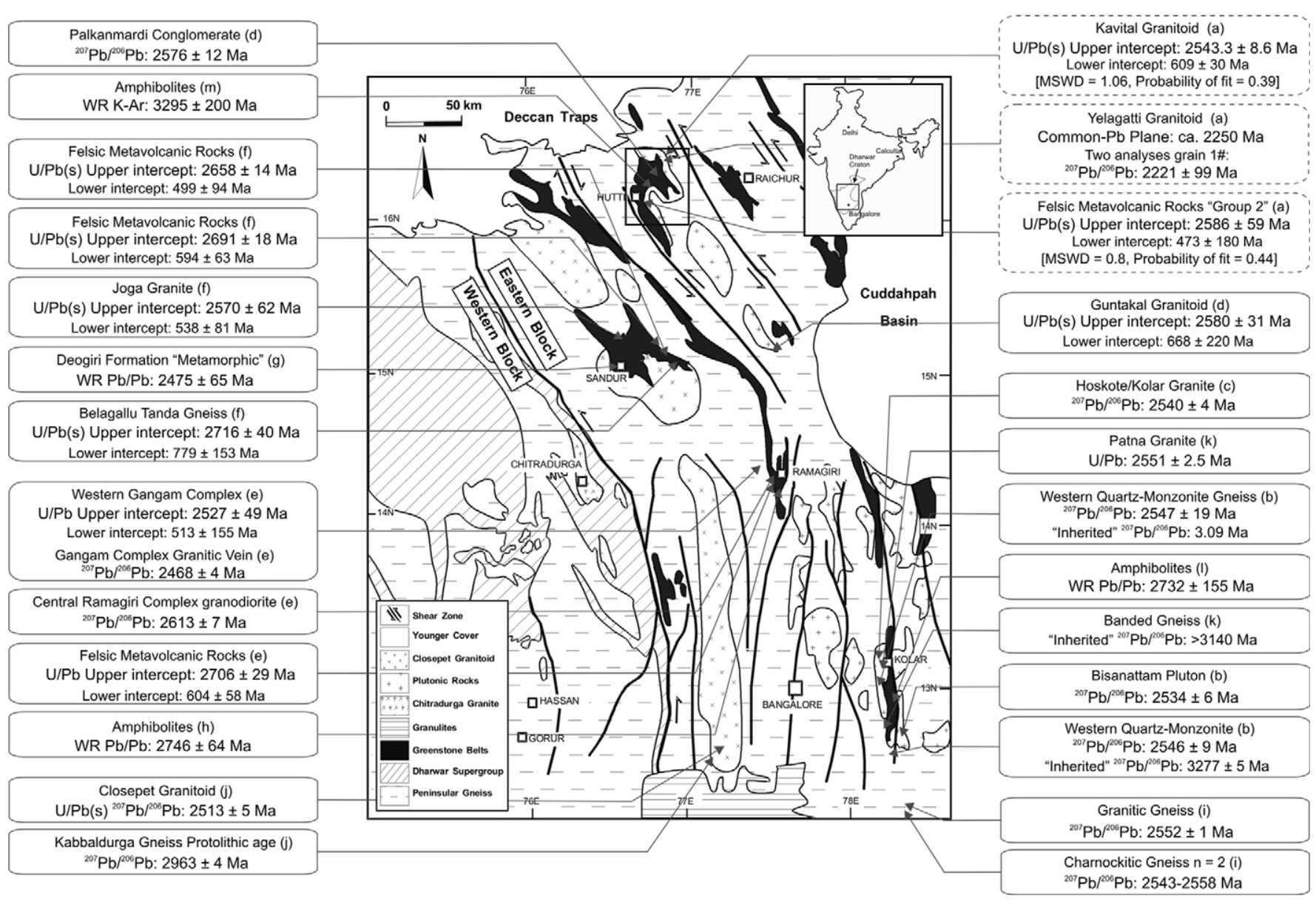

Fig. 1. Schematic geological map of the Dharwar Craton, modified after Chadwick et al. (2000), Jayananda et al. (2000) and Moyen et al. (2003). The geochronological data recorded in the eastern block has been added: (a) this study; (b) Chardon et al. (2002); (c) Jayananda et al. (2000); (d) Vasudev et al. (2000); (e) Balakrishnan et al. (1999); (f) Nutman et al. (1996); (g) Russell et al. (1996); (h) Zacharaiah et al. (1995); (i) Peucat et al. (1993); (j) Friend and Nutman (1991); (k) Krogstad et al. (1991); (l) Balakrishnan et al. (1990) and (m) Sarkar (1968). Abbreviations used include: U/Pb(s), U/Pb isotope method (SHRIMP); WR $\mathrm{Pb} / \mathrm{Pb}$, whole rock common- $\mathrm{Pb}$ method and ${ }^{207} \mathrm{~Pb} /{ }^{206} \mathrm{~Pb},{ }^{207} \mathrm{~Pb} /{ }^{206} \mathrm{~Pb}$ model age. The defined area is the Hutti-Maski Greenstone Belt (HMGB), enlarged in Fig. 2.

southern section of the Closepet Granite. The subsequent mantle melting resulted in widespread magmatism between 2550 and $2520 \mathrm{Ma}$ as well as magmatic accretion of lower crust and granulite facies metamorphism (Chardon et al., 2002; Jayananda et al., 2000). This steep advective geotherm lowered the viscosity of the crust and triggered the sagduction of the Kolar Greenstone Belt around $2530 \mathrm{Ma}$, highlighted by a normal shear zone to the west of the belt (Chardon et al., 2002).

In this paper, petrology and geochemistry are used to distinguish and classify the basement rocks, amphibolites and granitoid intrusions associated with the HMGB. Zircons from the felsic metavolcanic rocks and granitoids were analysed using a Sensitive High Resolution Ion Micro Probe (SHRIMP). In addition, geochronological data for the eastern block of the Dharwar Craton has been collected and summarised so that the HMGB can be integrated into this cratonic framework, leading to a greater understanding of the duration and spatial distribution of the late Archean magmatism and tectonism.

\section{Geological setting}

The Dharwar Craton occupies an area of $400,000 \mathrm{~km}^{2}$ in southern India, lying between the latitudes $12^{\circ} 0^{\prime}$ and $18^{\circ} 0^{\prime} \mathrm{N}$ and longitudes $74^{\circ} 0^{\prime}$ and $80^{\circ} 0^{\prime} \mathrm{E}$ (Fig. 1). The low-lying area to the east is masked by Meso- to Neoproterozoic sediments of the Cuddapah Supergroup. To the south of the craton, granulite facies charnockites and khondalites dominate. Whereas, the Deccan Traps ( $\sim 65 \mathrm{Ma}$ ), extend across the northern margin of the craton.

The Dharwar Craton is dominated by Tonalite-Trondhjemite-Granodiorite (TTG) gneisses, Greenstone Belts, deep crustal granulite sections and subordinate calcalkaline to K-rich granites (Fig. 1). Variations in the ages of the Greenstone and gneiss units, the volcano-sedimentary environments, magmatism and the general grade of metamorphism, have led to the subdivision of the craton into two blocks. The Closepet Granite (Smeeth, 1915) positioned along the boundary between the eastern and western blocks, is the youngest of the late Archean granitoids 
$(2513 \pm 5 \mathrm{Ma}$; Friend and Nutman, 1991). The microstructural fabrics of this elongate ( $400 \mathrm{~km}$ long, $30 \mathrm{~km}$ wide) syn-tectonic granite indicate that it was emplaced into a dextral strike-slip shear zone (Jayananda and Mahabaleshwar, 1991; Moyen et al., 2003), representing the final phase of tectono-magmatic activity in the Dharwar Craton (Drury et al., 1984; Moyen et al., 2003).

\subsection{Eastern block}

The eastern block of the Dharwar Craton has a basement unit, which includes banded, streaky and biotite granitic gneisses grouped under the term Peninsular Gneiss (Smeeth, 1915; Srikantia, 1995). Srikantia (1995) applied this nomenclature to convey the strong similarities between the basement units in the eastern and western blocks. Whereas, Chadwick et al. (2000) grouped the entire plutonic complex under the term Dharwar Batholith, due to the close lithological similarity, structural coherence and emplacement of its key components between ca. 2750 and $2510 \mathrm{Ma}$. Geochronological data has been summarised in Fig. 1, where several ages have been documented (e.g. Kolar Greenstone Belt), those generated with high precision and/or minimal errors have been cited, for a complete listing the readers are referred to Krogstad et al. (1991), Peucat et al. (1993), Balakrishnan et al. (1999), Jayananda et al. (2000) and Chardon et al. (2002). The oldest recorded age was recovered from the Western Quartz-Monzonite to the south of the Kolar Greenstone Belt. It contains inherited zircons with ${ }^{207} \mathrm{~Pb} /{ }^{206} \mathrm{~Pb}$ ages of $3277 \pm 5 \mathrm{Ma}$, which is interpreted as a xenocryst incorporated into a younger magma (Chardon et al., 2002; Fig. 1).

There are numerous Greenstone Belts (volcano-sedimentary units) distributed throughout the block, however, only four have been dated (Fig. 1): (1) Hutti-Maski (3295 $\pm 200 \mathrm{Ma}, \quad$ Sarkar 1968); (2) Ramagiri $(2706 \pm 29 \mathrm{Ma}$, Balakrishnan et al., 1999 as well as $2746 \pm 64 \mathrm{Ma}$, Zacharaiah et al., 1995); (3) Kolar (2732 \pm 155 Ma, Balakrishnan et al., 1990) and (4) Sandur (2691 $\pm 18 \mathrm{Ma}$ and $2658 \pm 14 \mathrm{Ma}$, Nutman et al., 1996). Igneous units have subsequently intruded into these belts, during widespread magmatism, including juvenile and anatectic granites, granodiorites, monzonites and diorites. Jayananda et al. (2000) defined a younger group of juvenile intrusions (2550-2520 Ma) to the SW of the block. Chadwick et al. (1997) linked this voluminous granitoid emplacement with high temperature Greenschist to amphibolite facies metamorphism during the late Archean.

Shear zone systems comparable to those in the west are also abundant in the eastern block, associated in particular with the Sandur, Ramagiri-Hungund, Hutti-Kolar, Raichur-Kadri and Narayanpet-Gadwal Greenstones Belts (Fig. 1; Manikyamba et al., 2004). A cease in the tectonic activity has been recorded in the Ramagiri Greenstone Belt using a post-kinematic granitic vein, dated at $2468 \pm 4$ Ma. A later isotopic disturbance can be correlated with that of the Pan-African orogeny in the shear zones to the south of the Dhawar Craton (Hansen et al., 1985). The lower intercept ages from the Guntakal granitoid (Vasudev et al., 2000), Ramagiri felsic metavolcanic rocks, Western Gangam granodiorite (Balakrishnan et al., 1999), Belagallu Tanda gneiss, Sandur felsic metavolcanic rocks and the Joga granite (Nutman et al., 1996) all recorded a Pb-loss (U-gain) sometime between 779 and $499 \mathrm{Ma}$ (excluding errors; Fig. 1).

\section{Hutti-Maski Greenstone Belt}

The Hutti-Maski Greenstone Belt (HMGB) lies between the latitudes $16^{\circ} 20^{\prime}$ and $15^{\circ} 40^{\prime}$ and longitudes $76^{\circ} 35^{\prime}$ and $76^{\circ} 55^{\prime}$, occupying an area of $500 \mathrm{~km}^{2}$ in the northeast of the Dharwar Craton (Fig. 2). The outline of the belt is elongate $(80 \mathrm{~km}$ long), with the northern end slightly rotated to the east, forming a hook shape. The lithologies surrounding the belt are plutonic with either a tectonic or intrusive contact, often indistinguishable due to poor outcrop (Roy, 1979; Srikantia, 1995). The western boundary of the belt is tectonically juxtaposed to the basement rock (Peninsular Gneiss; Srikantia, 1995). Along the northern, eastern and southern contacts two granitoids can be distinguished, Kavital and Yelagatti (Srikantia, 1995; Fig. 2).

The stratigraphic column defined in the HMGB is dominated by metavolcanic rocks ( $>90 \%$, amphibolites and felsic metavolcanic rocks) with subordinate metasediments classified in the Hutti Group (Srikantia, 1995), which is subdivided into a number of formations (Hussainpur, 530 Hill, Bullapur and Buddinne; oldest to youngest, Srikantia, 1995). These lithologies were affected by a total of 5

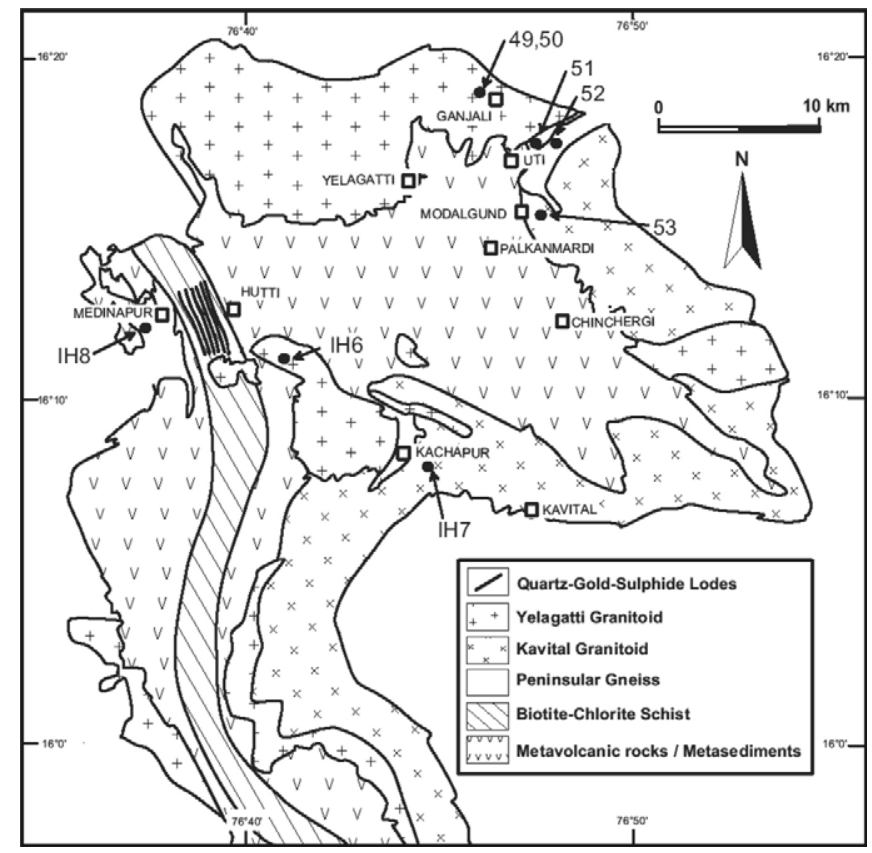

Fig. 2. Schematic geological map of the Hutti-Maski Greenstone Belt, including the location of the auriferous shear zones at Hutti and the sample locations (IH6, IH7, IH8, 49, 50, 51, 52 and 53), modified after Roy (1979) and Srikantia (1995). 
deformation events $\left(D_{1}-D_{5}\right)$, three of which were synchronous with three metamorphic stages $\left(D_{1} / M_{1}, D_{2} / M_{2}\right.$ and $\left.D_{3} / M_{3}\right)$. Subsequent to peak metamorphism ductile shearing $\left(D_{2} / M_{2}\right)$ formed 9 auriferous $(<5 \mathrm{~g} / \mathrm{t} \mathrm{Au})$ shear zones (up to $10 \mathrm{~m}$ wide) commonly associated with the amphibolite-felsic metavolcanic rock contact (Fig. 3). The shear zones were then reactivated under dextral strike-slip shearing $\left(D_{3} / M_{3}\right)$, during which auriferous laminated quartz veins formed. Contemporaneously with the development of the major brittle-ductile shear zone, the syn-tectonic Kavital granitoid intruded into the belt (Srikantia, 1995). Later deformation events are characterised by locally developed kink bands or cross-cutting, quartz-chlorite-calcite veinlets $\left(D_{4}\right)$ and faults $\left(D_{5}\right.$; Kolb et al., 2005). The Yelagatti granitoid subsequently intruded into both the shear zones positioned to the south of the Hutti Mine (Fig. 2) and the Kavital granitoid (Srikantia, 1995).

The only age recorded for the metavolcanic rocks of the HMGB is a solitary whole rock $\mathrm{K}-\mathrm{Ar}$ age of $3295 \pm 200 \mathrm{Ma}$ (Sarkar, 1968; Fig. 1). Nevertheless, the belt is usually accepted as Archean (Radhakrishna, 1983; Radhakrishna and Vasudev, 1977; Ramakrishnan et al., 1976; Roy, 1979; Swaminath and Ramakrishnan, 1981). The Palkanmardi conglomerate marks the base of the stratigraphic sequence (Vasudev et al., 2000), an admixture of sedimentary detritus and contemporaneous volcanic/ volcaniclastic components (Roy and Biswas, 1982). A granitoid pebble from this conglomerate generated a weighted mean ${ }^{207} \mathrm{~Pb} /{ }^{206} \mathrm{~Pb}$ zircon age of $2576 \pm 12 \mathrm{Ma}$ (Vasudev et al., 2000). This can be correlated with the Guntakal granitoid, which yielded a concordia upper intercept age of $2580 \pm 31 \mathrm{Ma}$ (Vasudev et al., 2000; Fig. 1). These ages are indistinguishable and are interpreted as the magmatic crystallisation age of the granodiorite. Based on these dates and the stratigraphic position of the Palkanmardi conglomerate, Srikantia (1995) and Vasudev et al. (2000) implied that basin development (volcanism and sedimenta-

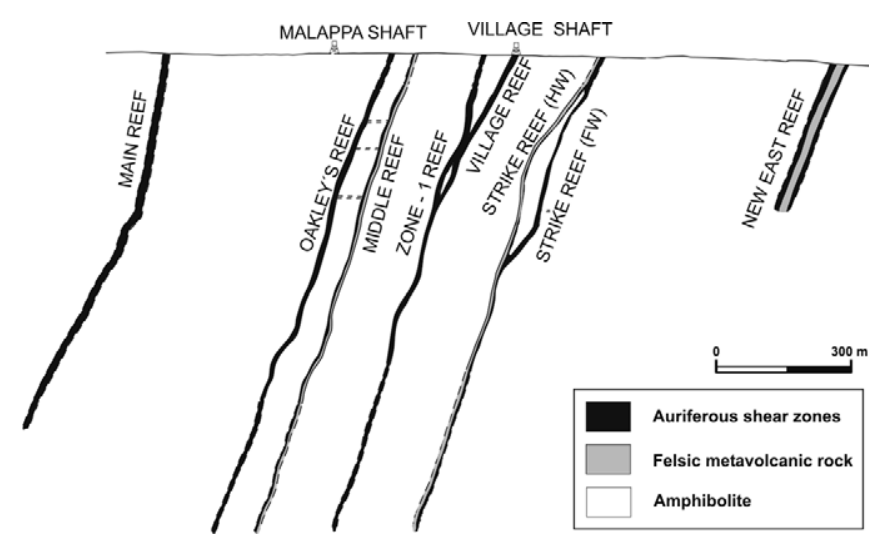

Fig. 3. Cross-section of the Hutti Gold Mine through the Malappa and Village shafts, the auriferous shear zones and their close spatial relationship with the felsic metavolcanic rocks, is clearly illustrated, a Hutti Gold Mines Co., Ltd., mining plan. tion) in the HMGB was rapid and began very late in the evolution of the craton.

\section{Analytical methods}

The samples were analysed for mineral species using a Siemens D-500 X-ray Diffractometer (XRD) and major elements using a Phillips PW-1400 wavelength dispersive X-ray Fluorescence spectrometer (XRF) at the RWTH Aachen University. The trace and Rare Earth Elements (REE) however, were analysed using Instrumental Neutron Activation Analysis (INAA) and Inductively Coupled Plasma-Mass Spectroscopy (ICP-MS) at the Activation Laboratories Ltd., Canada.

Zircons for the geochronological analyses were separated and analysed with the SHRIMP II at the Research School of Earth Sciences (RSES), together with the reference zircons FC1 and SL13. For calibration purposes the $\mathrm{Pb} / \mathrm{U}$ ratios have been normalised relative to a value of 0.1859 for the ${ }^{206 *} \mathrm{~Pb} /{ }^{238} \mathrm{U}$ ratio of the $\mathrm{FC} 1$ reference zircons, equivalent to an age of $1099 \mathrm{Ma}$ (Paces and Miller, 1989). Concentrations of $U$ and $T h$ were determined relative to the SL13 standard and the common- $\mathrm{Pb}$ was corrected using the measured ${ }^{204} \mathrm{~Pb}$. Uncertainties given for individual analyses (ratios and ages) are at the $1 \sigma$ level and uncertainties in the calculated weighted mean ages are reported as $95 \%$ confidence. A comprehensive account of the analytical procedures as well as data assessment are fully explained in Compston et al. (1984), Roddick and van Breemen (1994) and Claoué-Long et al. (1995). The data reduction technique are similar to that described by Williams (1998 and references therein), using the SQUID Excel Macro of Ludwig (2000). Conventional U-Pb Wetherill concordia plots and weighted mean age calculations were carried out using Isoplot/Ex (Ludwig, 1999).

\section{Petrological and geochemical analyses}

The three main rock units have been identified and sampled based on the most detailed regional mapping, descriptions and nomenclature of Srikantia (1995; Fig. 2): (1) gneiss (basement rock); (2) metavolcanic rocks (amphibolites and felsic metavolcanic rocks) and (3) plutonic units (Kavital and Yelagatti granitoids).

\subsection{Basement rock}

The basement rock is typically grey with a distinctive gneissic fabric. The Medinapur gneiss (IH8) sampled to the west of the HMGB (Fig. 2) is medium-grained with a pale grey colour; a strong foliation is defined by $0.5 \mathrm{~cm}$ long quartz ribbons. The main components of the rock are plagioclase and quartz, with traces of K-feldspar, chlorite, sericite, calcite, prehnite and kaolinite. The Uti gneiss (52) sampled between the Yelagatti and Kavital granitoids to the northeast (52; Fig. 2) is medium- to coarse-grained with a dark grey colour. The main component of the rock 
is plagioclase, with smaller amounts of quartz, K-feldspar, biotite, amphibole, sericite and kaolinite. The Uti gneiss (52) in comparison to the Medinapur gneiss (IH8) has less $\mathrm{SiO}_{2}$, more $\mathrm{Fe}_{2} \mathrm{O}_{3}, \mathrm{MgO}$ as well as $\mathrm{CaO}$ and a significantly lower $\mathrm{Na}_{2} \mathrm{O} / \mathrm{K}_{2} \mathrm{O}$ ratio (Table 1). Chemically, these gneisses are classified as Trondhjemite, characteristic for the Archean crust (Martin, 1994). The concentrations of the transition metals $\mathrm{Cr}, \mathrm{Ni}, \mathrm{Sc}, \mathrm{V}$ as well as $\mathrm{Rb}$ and $\mathrm{Sr}$ are consistently lower for the Medinapur than the Uti gneiss. The $\mathrm{La}_{n}$ content of the Medinapur gneiss is 85 times, lower than that of the Uti gneiss and the $\sum \mathrm{REE}$ is also appreciably lower, in addition to their contrasting $\mathrm{Eu}$ anomalies (Fig. 4).

\subsection{Metavolcanic rocks}

The metavolcanic rocks were sampled and analysed 23 times ( 15 amphibolites and 8 felsic metavolcanic rocks) in the Hutti Gold Mine, from the Buddinne Formation, Hutti Group (Biswas et al., 1985; Rajamani et al., 1985; Biswas, 1990; Raju and Sharma, 1991). The amphibolites are dark grey with a greenish discolouration compared to the pale grey interbeds of the subordinate and laterally discontinuous felsic metavolcanic rocks. Pillows are abundant within the amphibolites and can used to define a westward younging direction, vesicular textures, were lacking.

The amphibolites are dominated by amphibole, which makes up to $78 \mathrm{wt} \%$, randomly orientated in a matrix of plagioclase $(20 \mathrm{wt} \%)$, ilmenite, chlorite, epidote and sericite. Two types of felsic metavolcanic rocks can be distinguished: (1) a porphyritic texture with large $(1 \mathrm{~mm})$ plagioclase grains and a finer matrix $(50-70 \mu \mathrm{m})$ of plagioclase, quartz and muscovite, and (2) coarser grained (plagioclase and quartz, $5 \mathrm{~mm}$ ) in an equigranular matrix of plagioclase, quartz, muscovite, chlorite, calcite and sericite.

The amphibolites have a basaltic to basaltic-andesitic composition and can be classified as tholeiitic using the ternary system $\mathrm{FeOt}-\mathrm{Na}_{2} \mathrm{O}+\mathrm{K}_{2} \mathrm{O}-\mathrm{MgO}$. The chondrite $\left(C_{1}\right)$ normalised REE plot is relatively flat with a slight decrease in the LREE and only marginally fractionated the HREE (Fig. 5a). The amphibolites as a whole appear to be chemically similar and relatively unaltered, as the incompatible elements have a moderate correlation $(\mathrm{Rb}$

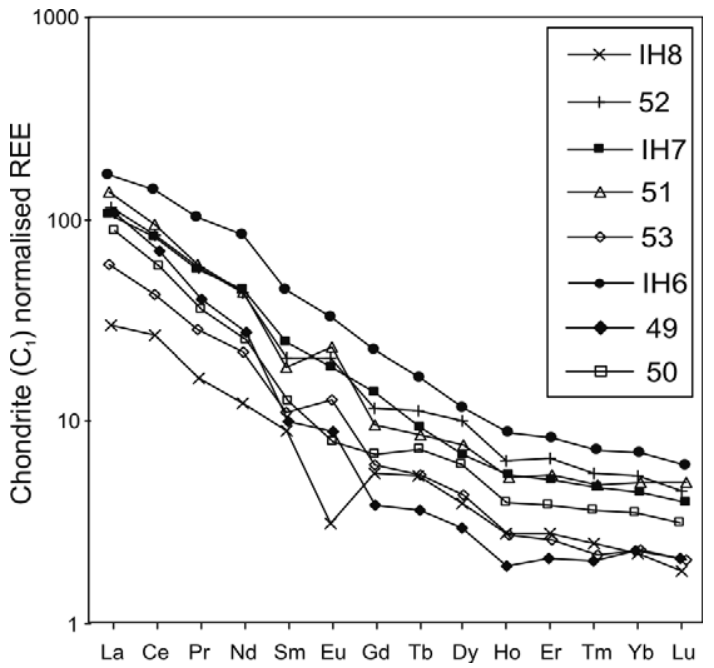

Fig. 4. Chondrite $\left(C_{1}\right)$ normalised REE patterns, for the igneous lithologies, values from Sun and McDonough (1989).

against Cs, $r^{2}=0.7$ ), which would be unexpected if alteration had thoroughly modified the major and trace element compositions. Although, the correlations between the major elements are weak, e.g. the $\mathrm{Mg}$ number varies between 39 and 54 . The relatively wide range of $\mathrm{MgO}(4$ $8 \mathrm{wt} \%), \mathrm{TiO}_{2}(0.8-1.2 \mathrm{wt} \%)$ and $\mathrm{Zr}(42-67 \mathrm{wt} \%)$ may indicate some degree of fractionational crystallisation, although further attention is unfounded due to the uncertainties accompanying the hydrothermal activity as well as the fundamental variations between the individual volcanic episodes. Chemical, enrichments in $\mathrm{Ba}, \mathrm{Nb}, \mathrm{Th}$, LREE and $\mathrm{Ta}$ with depletions in $\mathrm{Ti}, \mathrm{Sr}$ and $\mathrm{Cr}$ can be distinguished when going up through the stratigraphic column. The fractionation of the REE (Fig. 5b), the change in the Eu anomaly (positive to negative) as well as the element variations may reflect fractionation of the magma source, becoming enriched with time.

\subsection{Plutonic units}

\subsubsection{Kavital granitoid}

The Kavital granitoid sampled from the NE of Uti (51) and to the east of the Modalgund village (53, Fig. 2) are both medium-grained rocks with a pale grey colour. The

Table 1

Geochemical analysis of the main oxides from the basement and plutonic rocks

\begin{tabular}{|c|c|c|c|c|c|c|c|c|c|c|c|c|}
\hline Sample & Description & $\begin{array}{l}\mathrm{SiO}_{2} \\
(\%)\end{array}$ & $\begin{array}{l}\mathrm{TiO}_{2} \\
(\%)\end{array}$ & $\begin{array}{l}\mathrm{Al}_{2} \mathrm{O}_{3} \\
(\%)\end{array}$ & $\begin{array}{l}\mathrm{Fe}_{2} \mathrm{O}_{3} \\
(\%)\end{array}$ & $\begin{array}{l}\mathrm{MnO} \\
(\%)\end{array}$ & $\begin{array}{l}\mathrm{MgO} \\
(\%)\end{array}$ & $\begin{array}{l}\mathrm{CaO} \\
(\%)\end{array}$ & $\begin{array}{l}\mathrm{Na}_{2} \mathrm{O} \\
(\%)\end{array}$ & $\begin{array}{l}\mathrm{K}_{2} \mathrm{O} \\
(\%)\end{array}$ & $\begin{array}{l}\mathrm{P}_{2} \mathrm{O}_{5} \\
(\%)\end{array}$ & $\begin{array}{l}\text { LOI } \\
(\%)\end{array}$ \\
\hline IH8 & Medinapur gneiss (basement) & 75.76 & 0.10 & 13.60 & 0.78 & 0.02 & 0.38 & 1.76 & 6.38 & 0.54 & 0.02 & 0.86 \\
\hline 52 & Uti gneiss (basement) & 66.98 & 0.52 & 14.66 & 5.35 & 0.07 & 2.04 & 3.13 & 4.31 & 2.17 & 0.17 & 1.02 \\
\hline 51 & Uti granodiorite (Kavital) & 60.27 & 0.41 & 18.36 & 4.28 & 0.07 & 1.68 & 3.26 & 5.78 & 3.66 & 0.19 & 1.14 \\
\hline 53 & Modalgund granodiorite (Kavital) & 71.24 & 0.28 & 15.00 & 2.38 & 0.03 & 0.83 & 2.93 & 5.42 & 1.99 & 0.08 & 0.72 \\
\hline IH7 & Kachapur granodiorite (Kavital) & 67.11 & 0.41 & 15.75 & 3.52 & 0.05 & 1.53 & 3.47 & 5.13 & 2.19 & 0.17 & 1.02 \\
\hline IH6 & Hutti granodiorite (Yelagatti) & 63.29 & 0.64 & 15.89 & 4.52 & 0.07 & 2.48 & 4.41 & 6.14 & 2.46 & 0.23 & 0.93 \\
\hline
\end{tabular}



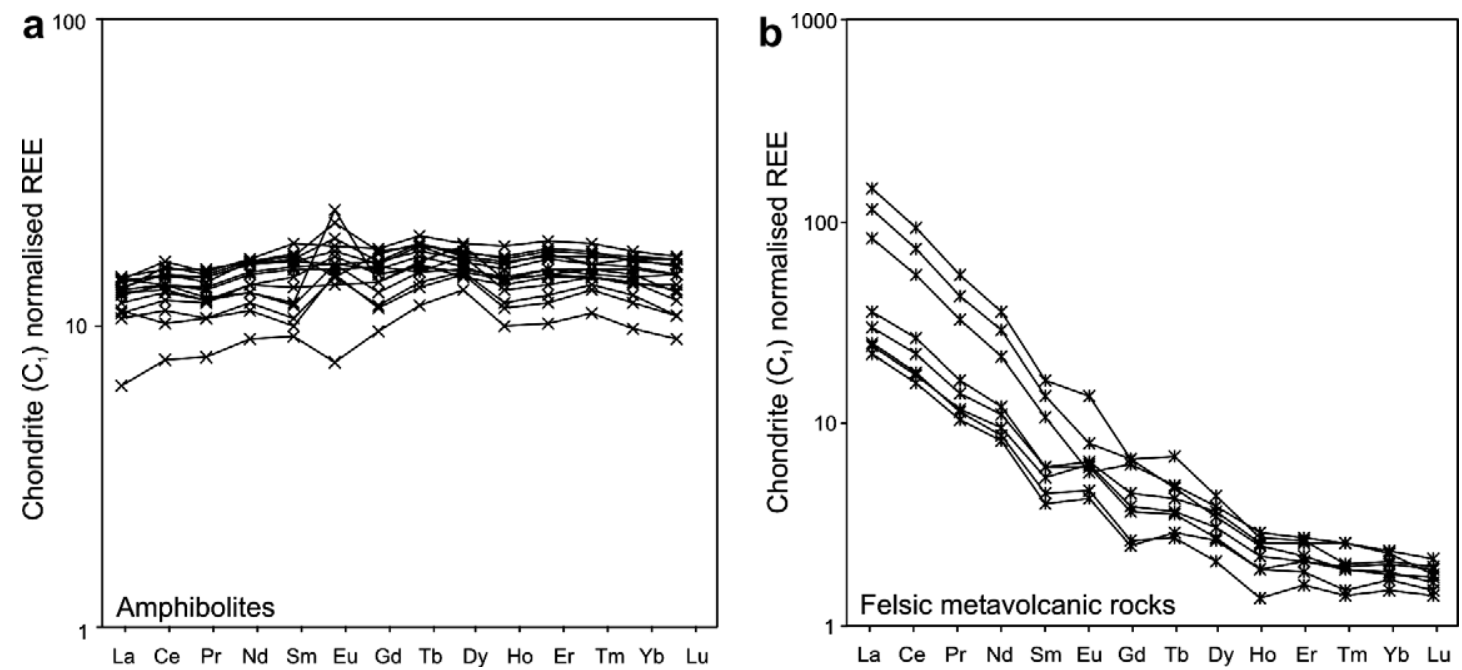

Fig. 5. Chondrite $\left(C_{1}\right)$ normalised REE patterns, values from Sun and McDonough (1989) for: (a) amphibolites $(n=15)$, and (b) felsic metavolcanic rocks $(n=8)$.

most dominant minerals are plagioclase and quartz with minor biotite, epidote, chlorite, sphene and sericite. Whereas, at the third location to the east of Kachapur (IH7, Fig. 2) the rock is medium-grained with a dark grey colour, dominated by plagioclase and quartz, with minor K-feldspar, amphibole, biotite, sphene, epidote and muscovite. The major elements vary slightly $\mathrm{SiO}_{2} 60-71 \mathrm{wt} \%$, $\mathrm{TiO}_{2} \quad 0.3-0.4 \mathrm{wt} \%, \mathrm{Al}_{2} \mathrm{O}_{3} 15.8-18.4 \mathrm{wt} \%$, in addition to high $\mathrm{Na}_{2} \mathrm{O} / \mathrm{K}_{2} \mathrm{O}$ ratios (Table 1 ). The chondrite $\left(C_{1}\right)$ normalised REE patterns are strongly fractionated with a similar degree of fractionation for both the LREE and HREE. The granitoid can be classified as a homogenous, granodiorite unit chemically similar to Archean TTG suites (Fig. 4).

\subsubsection{Yelagatti granitoid}

The Yelagatti granitoid to the west of Ganjali has a strong colour variation from grey to the more common pink variety (samples 49 and 50, respectively, Fig. 2). Both rock types are fine-grained, dominated by $\mathrm{K}$-feldspar and quartz with subordinate plagioclase as well as minor amounts of biotite, chlorite, epidote and sphene. They are chemically very similar with ca. $75 \mathrm{wt} \% \mathrm{SiO}_{2}$, ca. $0.1 \mathrm{wt} \% \mathrm{TiO}_{2}$ and ca. $13 \mathrm{wt} \% \mathrm{Al}_{2} \mathrm{O}_{3}$. The chondrite $\left(C_{1}\right)$ normalised REE pattern of the grey granite (49) is enriched in the LREE, whereas the HREE in the pink granite (50) are slightly enriched compared to those of the grey granite. The Eu anomaly is slightly positive for the grey granite; whereas its pink counterpart is slightly negative (Fig. 4). At the third location, to the southeast of Hutti (IH6), Fig. 2 the rock was medium-grained with a pink to red colour, containing plagioclase (to a lesser extent quartz and $\mathrm{K}$-feldspar), with traces of amphibole, sphene and epidote. In comparison, this rock unit had a slightly lower $\mathrm{SiO}_{2}$ content $(63 \mathrm{wt} \%)$ but higher $\mathrm{TiO}_{2}$ and $\mathrm{Al}_{2} \mathrm{O}_{3}$ contents $(0.6$ and $16 \mathrm{wt} \%$, respectively) with both the LREE and HREE being enriched. In contrast, to the Kavital granitoid the
Yelagatti granitoid is heterogeneous, granite with a calcalkaline affinity but also granodioritic, similar to Archean TTG suites (Fig. 4).

\subsection{Tectonic evolution}

The amphibolites, when normalised to MORB, are characterised by the selective enrichment of low ionic potential elements ( $\mathrm{K}, \mathrm{Rb}, \mathrm{Ba}$ and $\mathrm{Th}$ ) compared to the depletion of high ionic potential elements $(\mathrm{Ta}, \mathrm{Nb}, \mathrm{Ce}, \mathrm{P}, \mathrm{Zr}, \mathrm{Hf}, \mathrm{Sm}$, Ti, Y, Yb and Cr; Fig. 6a). This pattern is typical of subduction related volcanic rocks reflecting the enrichment of the sub-arc mantle by fluids and melts derived from the subducting oceanic crust (MORB and pelagic sediment). The $\mathrm{Nb}$ anomaly (compared to $\mathrm{Th}$ and $\mathrm{Ce}$ ) is a typical signature of subduction related lithologies (Fig. 6a). The felsic metavolcanic rocks, when normalised to MORB, have marked positive anomalies of $\mathrm{Th}$ and $\mathrm{Ce}$ with negative $\mathrm{Nb}, \mathrm{P}$ and $\mathrm{Ti}$ anomalies (Fig. 6b). This indicates an affinity to a subduction setting, although the positive $\mathrm{Ce}$ anomaly may be related to the presence of epidote and the negative $\mathrm{P}$ and $\mathrm{Ti}$ anomalies to magnetite-dominated fractionation. The slight depletion of the HREE, Y and $\mathrm{Yb}$ relative to MORB and the change in the Eu anomaly (positive to negative), may also be explained by the fractional crystallisation of the magma, becoming enriched with time (Green, 1994; Rollinson, 1993; Sisson, 1994).

To illustrate the relationship between the amphibolites and felsic metavolcanic High Field Strength Elements (HFSE) can be used, $\mathrm{Hf}$ and $\mathrm{Zr}$ increase in concentration from the amphibolites to felsic metavolcanic rocks (correlation coefficient of 0.83 ; Fig. 7a), this is due to their incompatibility during tholeiitic magma differentiation (MacLean, 1990), suggesting one volcanic population. Individual lava flows therein can be highlighted by using the ratio $\mathrm{Th} / \mathrm{Yb}$, an increase is observed from the amphibolites up into the felsic metavolcanic rocks which have 

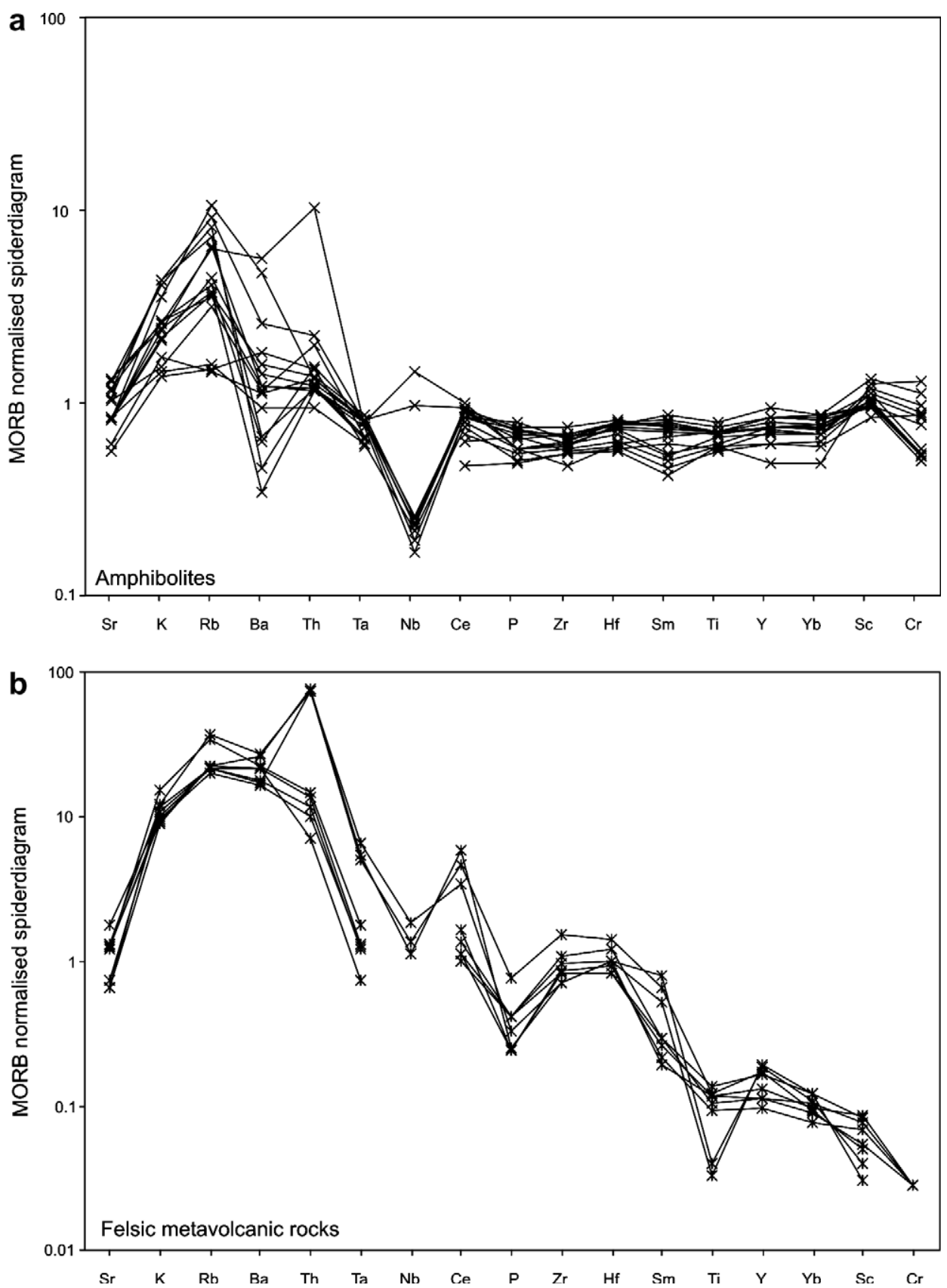

Fig. 6. MORB normalised spider-diagram, values from Pearce (1982), with the exception of Sc and Cr, which were taken from Pearce (1983): (a) amphibolites, characterised by an enrichment in the low ionic potential elements $\mathrm{K}, \mathrm{Rb}, \mathrm{Ba}$ and Th, compared to the depletion of high ionic potential elements $\mathrm{Ta}, \mathrm{Nb}, \mathrm{Ce}, \mathrm{P}, \mathrm{Zr}, \mathrm{Hf}, \mathrm{Sm}, \mathrm{Ti}, \mathrm{Y}, \mathrm{Yb}$ as well as $\mathrm{Cr}$, and (b) felsic metavolcanic rocks characterised by positive anomalies of $\mathrm{Th}$ and $\mathrm{Ce}$ with negative $\mathrm{Nb}, \mathrm{P}$ and $\mathrm{Ti}$ anomalies.

exceptionally high ratios (e.g. 47, representing a more evolved magma), the ratio then returns to a lower value in the overlying amphibolites (a cyclic pattern). Through extensive fractionation of a mafic tholeiitic parent magma, a rhyolitic end-member may form (Hart, 1984; Barrie and Shirey, 1991). On the other hand, Hf against $\mathrm{Y}$ indicates two distinct populations (Fig. 7b), although this pattern can be explained by the crystallisation of xenotime from the magma, which would deplete the $\mathrm{Y}$ and subsequently $\mathrm{P}$ relative to the amphibolites (Figs. $7 \mathrm{a}$ and $\mathrm{b}$ ).
All the plutonic units are low-metaluminous, based on $\mathrm{Al}$ saturation (i.e. molar proportions $\mathrm{Al}_{2} \mathrm{O}_{3} / \mathrm{CaO}+$ $\mathrm{Na}_{2} \mathrm{O}+\mathrm{K}_{2} \mathrm{O}$; Shand, 1927). Additionally, the absence of garnet and cordierite, the variable $\mathrm{Na}_{2} \mathrm{O} / \mathrm{K}_{2} \mathrm{O}$ ratio, high $\mathrm{Na}$ and low $\mathrm{Rb}$ concentrations as well as the presence of normative diopside (cf. Barker, 1979) indicate an I-Type affinity to the granitoids (cf. Chappell and White, 1974). The majority of these I-Type granitoids are classified as TTG (Fig. 8a), which is typical of the primitive Archean crust (Martin, 1994). The chief source of TTG may have 

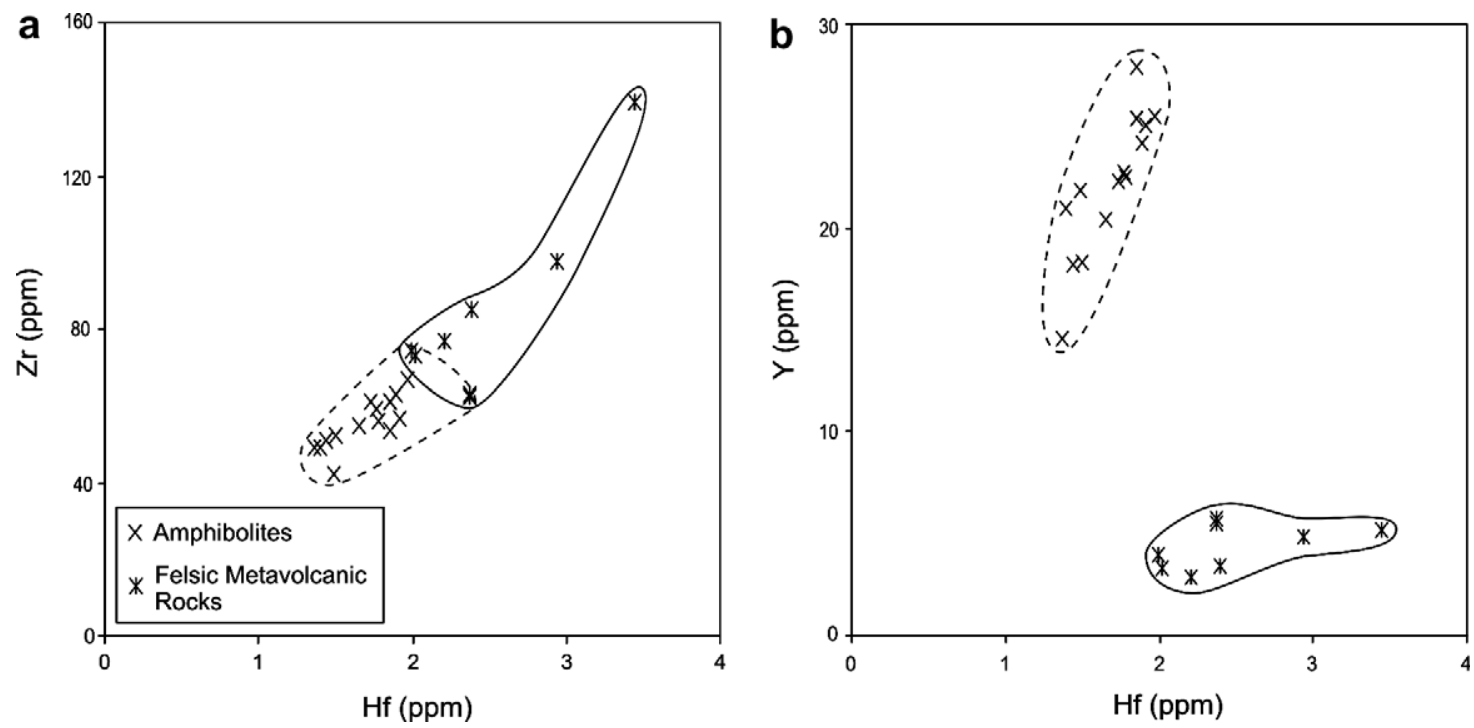

Fig. 7. Correlation plots between the amphibolites $(n=15)$ and felsic metavolcanic rocks $(n=8)$ : (a) Hf against $\mathrm{Zr}$, with a correlation coefficient of 0.83 indicating their incompatibility during tholeiitic magma differentiation and (b) Hf against Y defining two magma populations, see text for explanation.
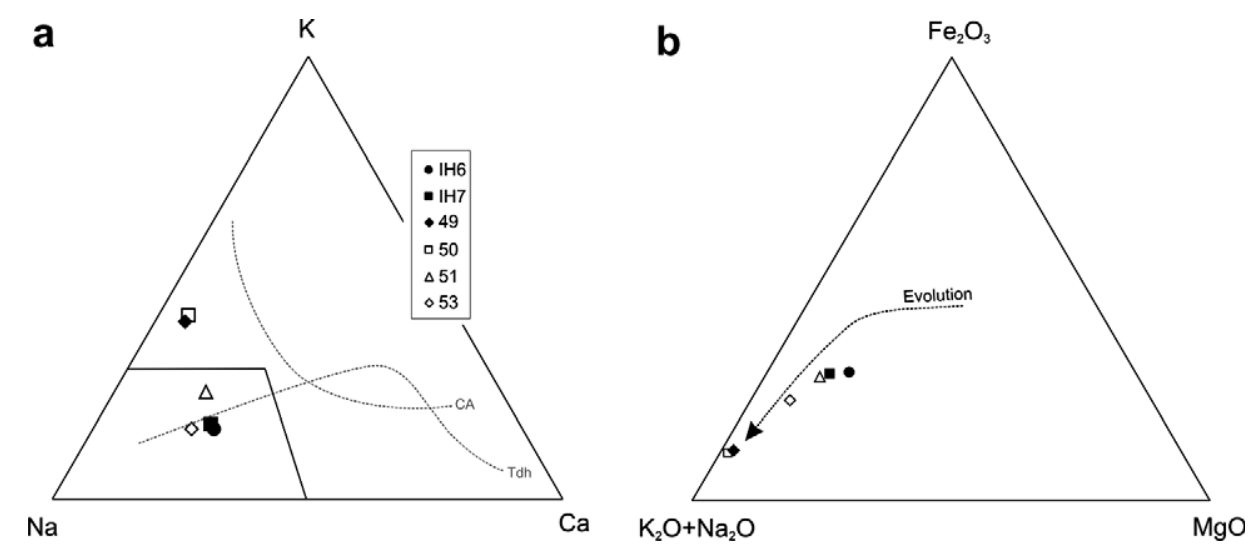

Fig. 8. (a) Ganjali granites are associated with the calc-alkaline trend (CA), with the rest of the samples not defining a trend (Trondhjemitic trend, Tdh) but rather a cluster towards the Na pole, indicating a Trondhjemitic affinity, trends are from Barker and Arth (1976) and (b) FAM plot, demonstrating a magma evolution path, defining the Hutti granodiorite (IH6) as the more primitive rock type, through to the more evolved Ganjali pink granite (50).

been the roots of thickening mafic crust, which were partially melted under hydrous conditions. The $\mathrm{Nb}$ anomaly in the primitive mantle normalised spider-diagram (Fig. 9) is a ubiquitous signature for modern calc-alkaline arc volcanics although strongly debated (Arculus and Powell, 1986; Briqueu et al., 1984). The $\mathrm{P}$ anomaly however, may reflect apatite fraction during differentiation and/ or, in combination with $\mathrm{Ti}$, magnetite-dominated fractionation (Fig. 9).

Most of the major oxides are negatively correlated with $\mathrm{SiO}_{2}$, except for the alkalis $\mathrm{Na}$ and $\mathrm{K}$. These patterns are typical of an evolving magma, supported by the FAM plot $\left(\mathrm{Fe}_{2} \mathrm{O}_{3}-\mathrm{K}_{2} \mathrm{O}+\mathrm{Na}_{2} \mathrm{O}-\mathrm{MgO}\right.$; Fig. 8b), which defines an evolution of the magma, from 52, IH6, IH7, 51, 53, 49 through to 50 . The higher $\mathrm{K}$ content in the Ganjali granites is also an indication of an evolved signature, in addition to an enrichment of $\mathrm{Rb}$ and depletion in $\mathrm{Sr}$ (cf. Sylvester, 1994). Brown et al. (1984) found that with increasing maturity, volcanic-arc granites are enriched in the elements $\mathrm{Rb}$, Th, U, Ta, Nb, Hf and $\mathrm{Y}$ and depleted in the elements $\mathrm{Ba}, \mathrm{Sr}, \mathrm{P}, \mathrm{Zr}$ and $\mathrm{Ti}$. This is particularly visible between the Ganjali granites (49 and 50) and the Uti and Modalgund granodiorites (51 and 53) on the primitive mantle normalised spider-diagram (Fig. 9), indicating the same evolution path as in the FAM plot (Fig. 8b).

\section{Geochronology}

The eruption age of the Greenstone Belts as well as the Greenstone-continent collision are critical for the understanding of the tectono-metamorphic evolution, consequently three samples were chosen for dating: (1) felsic metavolcanic rock, the sample with the highest $\mathrm{Zr}$ concentration was chosen (IH30, $\mathrm{Zr}=139 \mathrm{ppm})$; (2) Uti granodiorite (51, Kavital granitoid) particularly important due to its close proximity to the Yelagatti granitoid. If the Uti granodiorite 


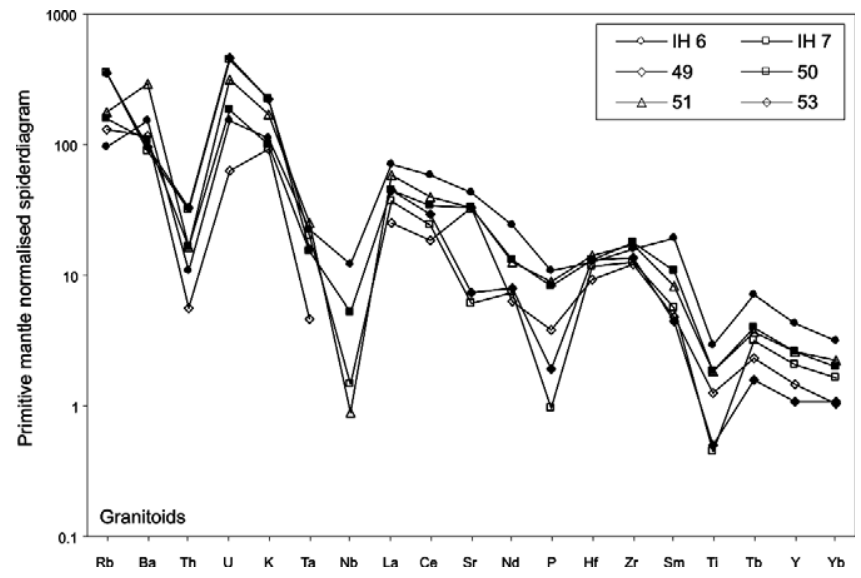

Fig. 9. Primitive mantle normalised spider-diagram, for the igneous lithologies, values from Taylor and McLennan (1985). Negative anomalies in $\mathrm{Th}, \mathrm{Nb}, \mathrm{P}$ and $\mathrm{Ti}$ are clearly definable; in particular a low concentration of $\mathrm{Nb}$ is a ubiquitous signature for modern calc-alkaline arc volcanics.

experienced contact metamorphism during the intrusion of the Yelagatti granitoid, this event may be recorded in the form of metamorphic overgrowths on the Uti granodiorite zircons, and (3) Ganjali pink granite (50, Yelagatti granitoid) as this granitoid is more commonly pink in colour, it seemed more appropriate to use this sample.

\subsection{Felsic metavolcanic rocks}

The zircons separated from the felsic metavolcanic rock (IH30) are heterogeneous, an adequate characterisation was difficult as the variations were subtle; confirmation was obtained using the cathodoluminescence (CL) imaging. Three groups can be identified: (1) acicular, subhedral zircons $80-120 \mu \mathrm{m}$ in length and lightly coloured. Small core like structures are visible in some of the grains (e.g. \#7.1 and 17.1) and oscillatory magmatic zoning is particularly prominent at their tips; CL imaging shows the zoning to be somewhat indistinct, probably due to later alteration. These grains are interpreted as the magmatic population; (2) similar to the Group 1 zircons in terms of form and size, but slightly darker. Core structures are discernible (e.g. grain 11\# and 17\#; Fig. 10a) with small magmatic tips similar to Group 1, and (3) again, similar to the preceding zircons (Groups 1 and 2) in terms of size, but rather than acicular, they are round as well as being darker in the CL images, core structures are also discernible (e.g. grain 14\# and 22\#; Fig. 10b).

The analyses were carried out in two sessions on the SHRIMP II, during which a total of 23 analyses were completed on 21 different grains. The Group 1 zircons were analysed 13 times on 13 different grains, the common- $\mathrm{Pb}$ contents range from $0.10 \%$ to $2.22 \%$ and the $\mathrm{U}$ and $\mathrm{Th} /$ U values from 667 to $2090 \mathrm{ppm}$ and $0.46-0.77$, respectively. The regression of the Group 1 zircons gives an upper intercept of $2523 \pm 44 \mathrm{Ma}$ and a lower intercept of $518 \pm 43 \mathrm{Ma}$ $(\mathrm{MSWD}=3.6 ;$ probability-of-fit $=0.00 ;$ Fig. 11a). The scarcity of the Group 2 zircons means there are only 4 analyses from 3 different grains; the common- $\mathrm{Pb}$ contents are low $(0.04-0.37 \%)$, with a range of $\mathrm{U}(677-1041 \mathrm{ppm})$ and $\mathrm{Th} / \mathrm{U}$ values $(0.61-0.79)$. These give an upper intercept age of $2586 \pm 59 \mathrm{Ma}$ and a lower intercept of $473 \pm 180 \mathrm{Ma} \quad(\mathrm{MSWD}=0.82 ; \quad$ probability-of-fit $=0.44$; Fig. 11a). The Group 3 zircons form a sub-population that is clearly very different; all 6 analyses have low common- $\mathrm{Pb}$ $(<0.08 \%)$, with a range of $\mathrm{U}(172-992 \mathrm{ppm})$ and $\mathrm{Th} / \mathrm{U}$ values $(0.05-0.39)$. There is no single coherent age population; however, all zircons are representative of the Mesoproterozoic (ca. 1180 Ma, analyses 10.1, 22.1 and 22.2 are reverse discordant; Fig. 11a).

The Group 1 zircons are texturally comparable with magmatic zircons. Their large uncertainties reflect the high discordance and scatter of the data $(2523 \pm 44 \mathrm{Ma})$. This could be a consequence of the relatively high $\mathrm{U}$ contents, attributed to alteration. The Group 2 zircons are slightly older $(2586 \pm 59 \mathrm{Ma})$ and may be inherited, although when the errors are taken into consideration this population is indistinguishable from Group 1. Therefore, the upper intercept age of $2586 \pm 59 \mathrm{Ma}$ from the Group 2 zircons provides a minimum eruption age of the felsic metavolcanic rocks. The Group 3 Mesoproterozoic zircons can be correlated with those identified in the later cross-cutting veinlets $\left(D_{4}\right)$.

\subsection{Kavital granitoid (Uti granodiorite, 51)}

The zircons separated are prismatic, euhedral to subhedral ranging in length from 100 to $250 \mu \mathrm{m}$ and yellow to red in colour. Fine oscillatory magmatic zoning is generally well preserved and identifiable in the majority of the grains (Fig. 10c), however, in areas of elevated $\mathrm{U}$ (CL inactive) the zircons are metamict and the zoning inconsistent (Fig. 10d). A few grains with small overgrowths (elevated U) were recognised although these rims were too altered to analyse.

A total of 17 analyses were completed on 17 different grains, the common- $\mathrm{Pb}$ contents vary between $0.22 \%$ and $1.22 \%$, with a range of $\mathrm{U}(388-886 \mathrm{ppm}$; excluding analysis 2.1 with $1175 \mathrm{ppm})$ and $\mathrm{Th} / \mathrm{U}$ ratios $(0.42-0.75$; excluding analysis 2.1 with 1.35 ). All the analyses are discordant but to varying amounts $3-74 \%$. The regression of the data produces a single discordia line with an upper intercept age of $2543 \pm 9 \mathrm{Ma}$ and a lower intercept of $609 \pm 30 \mathrm{Ma}$ $(\mathrm{MSWD}=1.1$; probability-of-fit $=0.39$; Fig. $11 \mathrm{~b})$. All the data points bar analysis 10.1 (Fig. 10c) were used; this analysis shows some variation from the overall trend. If this point is included, the calculated upper intercept age would remain unchanged but the probability-of-fit would significantly decrease.

The compositions are typical of magmatic zircons (cf. Nutman et al., 1996); therefore the upper intercept age is a well-defined minimum magmatic crystallisation age and consequently the emplacement age of the granitoid. The ${ }^{207} \mathrm{~Pb} /{ }^{206} \mathrm{~Pb}$ age of $2530 \pm 6 \mathrm{Ma}$ from the best analysis 

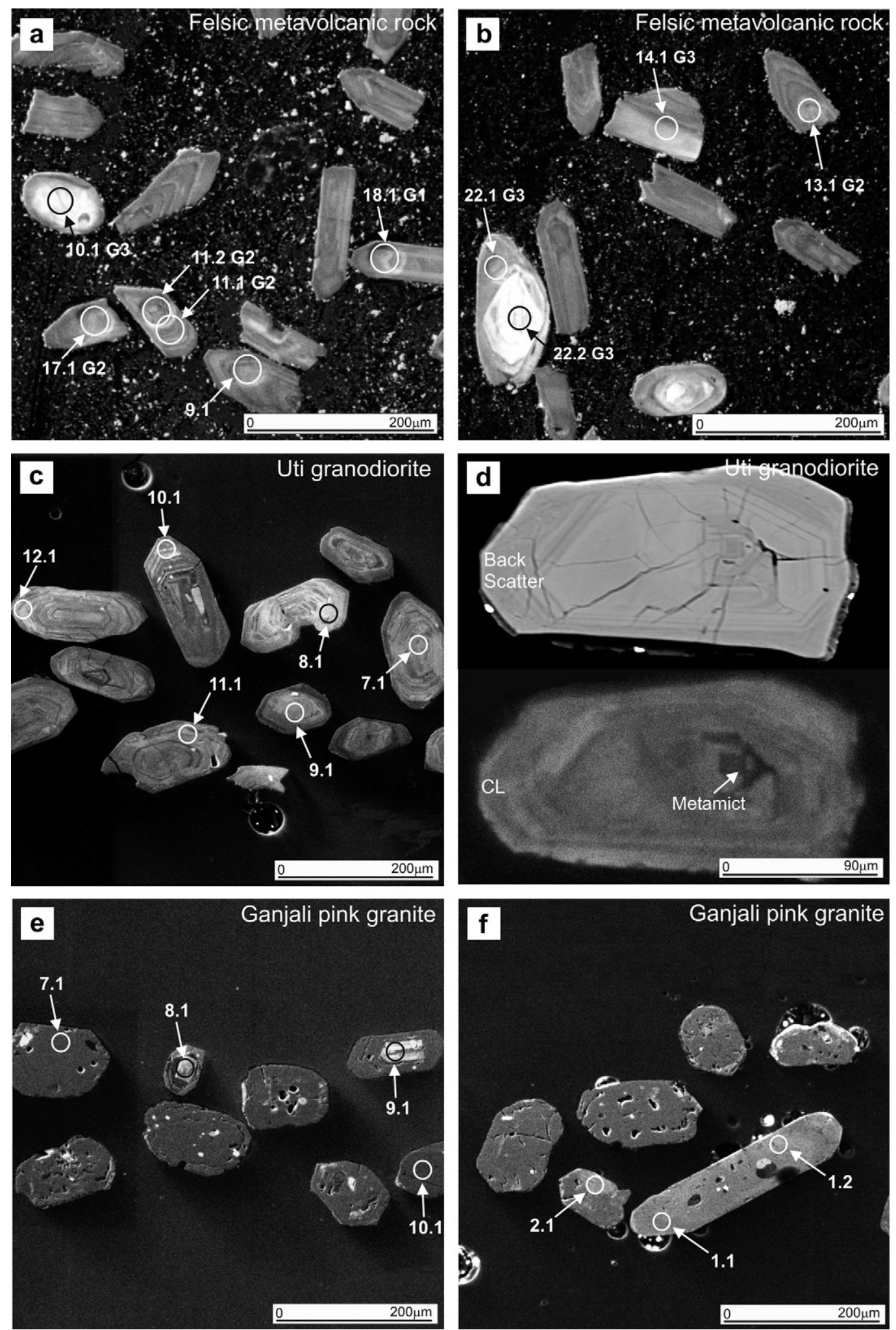

Fig. 10. Cathodoluminescence photomicrographs of some of the zircons from the: (a and b) felsic metavolcanic rock (IH30), core structures in particular can be distinguished ( $\mathrm{G}$ indicates the zircon group); (c) Uti granodiorite (51, Kavital granitoid), fine oscillatory magmatic zoning is clearly identifiable; (d) Uti granodiorite in areas of elevated U (CL inactive) the zircons are metamict and the zoning inconsistent; (e) Ganjali pink granite (50, Yelagatti granitoid), distinct core structures can be distinguished, e.g. grain 8\# and 9\# and (f) Ganjali pink granite, grain 1\# is unaltered and has a prismatic form, which differs from the rest of the population (analysis targets are marked). 

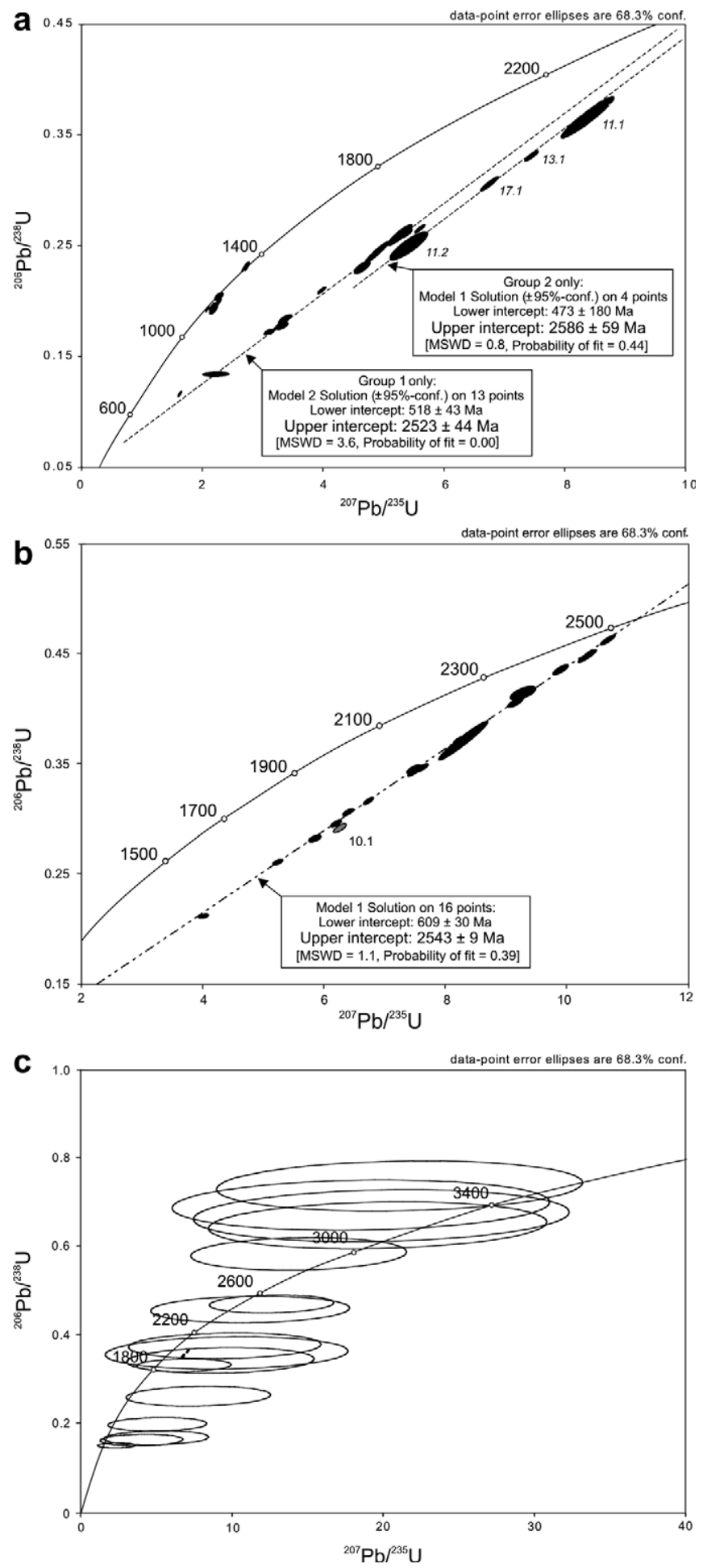

Fig. 11. U-Pb concordia plot for: (a) the felsic metavolcanic rock (IH30) showing the results of the zircon analyses for Groups 1 and 2 as well as the Group 3 concordia interceptions; (b) the Uti granodiorite (51) showing the positioning of the zircon analyses, including the regression line (excluding analysis 10.1) and subsequent concordia interceptions and (c) Ganjali pink granite (50) showing the positioning of the zircon analyses and their substantial errors, related to the common- $\mathrm{Pb}$ content.

(most concordant, 3\%) can therefore be regarded as an absolute minimum intrusion age, because of obvious ancient $\mathrm{Pb}$-loss (U-gain).

\subsection{Yelagatti granitoid (Ganjali pink granite, 50)}

The separated zircons are elongate $(100-250 \mu \mathrm{m})$ to round, mainly anhedral with a few subhedral grains, being pale yellow to red in colour. When the internal structures are observable, it is possible to distinguish between the cores and relic magmatic zoning (e.g. grain $8 \#$ and 9\#; Fig. 10e). The zircons are extremely altered and metamict (CL inactive), with the exception of grain 1\#, which is prismatic, differing from the rest of the population (Fig. 10f).

A total of 18 analyses were completed on 17 different grains, the zircons contain up to $47 \%$ common- $\mathrm{Pb}$ with equally extreme $\mathrm{U}$ and $\mathrm{Th}$ concentrations $(1.3 \%$ and $1.6 \%$, respectively). Only two analyses, taken from grain $1 \#$, are relatively normal in terms of $\mathrm{U}$, Th and common$\mathrm{Pb}$ contents (1696-1751 ppm, 79-321 ppm and 0.14-0.55\%, respectively), in contrast, the extreme concentrations from the majority of the analyses means that conventional regression is not applicable. The uncertainties (a function of the common- $\mathrm{Pb}$ ) are propagated to establish total uncertainties for individual analyses; these errors have become so large that the results are virtually meaningless in terms of geochronology.

The zircons are very vulnerable to the reliability of the common- $\mathrm{Pb}$ correction; this together with initial high radioactive element concentrations and intense post-crystallisation alteration has made it impossible to date these zircons using conventional techniques. Using more sophisticated techniques such as 3-D planar calculations (available in Isoplot) the common-Pb plane is intersected at approximately $2250 \mathrm{Ma}$, which is similar to the ${ }^{207} \mathrm{~Pb} /{ }^{206} \mathrm{~Pb}$ age for grain 1\#, $2221 \pm 99 \mathrm{Ma}$, Fig. 11c), this might be fortuitous considering the alteration, multi-episodic $\mathrm{Pb}$ loss (U-gain), and the inappropriateness of the U-Pb calibration for such high correction values, however, the ${ }^{207} \mathrm{~Pb} /{ }^{206} \mathrm{~Pb}$ age of $2221 \pm 99 \mathrm{Ma}$ may indicate a later event.

\section{Discussion}

The Hutti-Maski Greenschist Belt (HMGB) has undergone a complex evolution of metamorphism, deformation and granitoid intrusion. The findings presented, in light of the investigations undertaken can be used to construct a tectono-metamorphic evolution of the belt, which can be further integrated into the regional and consequently the cratonic setting.

\subsection{Hutti-Maski Greenstone Belt (HMGB)}

The areas of Trondhjemitic basement gneiss (Peninsular Gneiss), defined by Srikantia (1995), differ from one another both petrologically and chemically. Indeed, the Uti gneiss (52) displays similar chemical signatures to that of the Kavital samples (51 and 53; Fig. 4) and may therefore represent a gneissic rim formed during the syn-tectonic doming of the Kavital granitoid rather than the gneissic 
basement of the HMGB. The Medinapur gneiss (IH8) is petrologically and geochemically very similar to that of the Peninsular Gneiss in the region of Gorur, in the western block of the Dharwar Craton (cf. Bhaskar Rao et al., 1991; Fig. 1). However, this will remain ambiguous until adequate radiometric dating has been completed.

The amphibolites contain pillows and lack vesicles, indicating an eruption depth of at least $500 \mathrm{~m}$ below sea level (Fisher and Schmincke, 1984), typical of Archean Greenstones, in contrast to the post-Archean Greenstones, which are frequently associated with shallow water eruptions (Thurston, 1994). The minor amounts of felsic metavolcanic rocks and their variable thickness, imply non-resurgent, bimodal volcanism, conceivably with a migrating volcanic centre (Thurston, 1994). Regional plutonic activities as well as the trace element systematics of the amphibolite and felsic metavolcanic rocks infer an island-arc setting. This together with the lack of orientated dyke complexes and interbedded terrigenous clasts indicates a primitive-arc type setting. A minimum age of the HMGB volcanic activity can be defined by the $2586 \pm 59$ Ma age of the felsic metavolcanic rocks, which is consistent with the $2576 \pm 12 \mathrm{Ma}$ age for a granitoid pebble in the Palkanmardi conglomerate (Vasudev et al., 2000), yielding a maximum age for sedimentation in the HMGB (Figs. 1 and 12).
After the cease in volcanic activity, the volcanic pile was metamorphosed to amphibolite facies peak conditions as a result of crustal thickening and subsequently underwent retrograde metamorphism under a compressive tectonic regime. During this retrograde $\mathrm{P}-\mathrm{T}$ evolution, the two stages of gold mineralisation took place, at the greenschist/ amphibolite facies transition $\left(D_{2} / M_{2}\right)$ and under Greenschist facies conditions $\left(D_{3} / M_{3}\right.$; Kolb et al., 2004b, 2005). This second stage of mineralisation can be correlated with the intrusion of the Kavital TTG suite at $2543 \pm 9 \mathrm{Ma}$ (cf., Kolb et al., 2005; Srikantia, 1995). This I-Type granitoid suite most likely formed above an active subduction zone, in a progressively matured island-arc setting. The intrusion of the Yelagatti granitoid into the HMGB and Kavital granitoid may explain the altered appearance of the Kavital granitoid as well as the zones of metamorphic overgrowth on the zircons from the Uti granodiorite. The post-tectonic and post-metamorphic intrusion of the Yelagatti granitoid can be correlated with the end of the Archean, when the crustal production rates were low and the juvenile crust was no longer TTG, but calc-alkaline, with K-rich granitoids, derived through the re-melting of older felsic crust (Champion and Sheraton, 1997; Champion and Smithies, 2000; Sylvester, 1994).

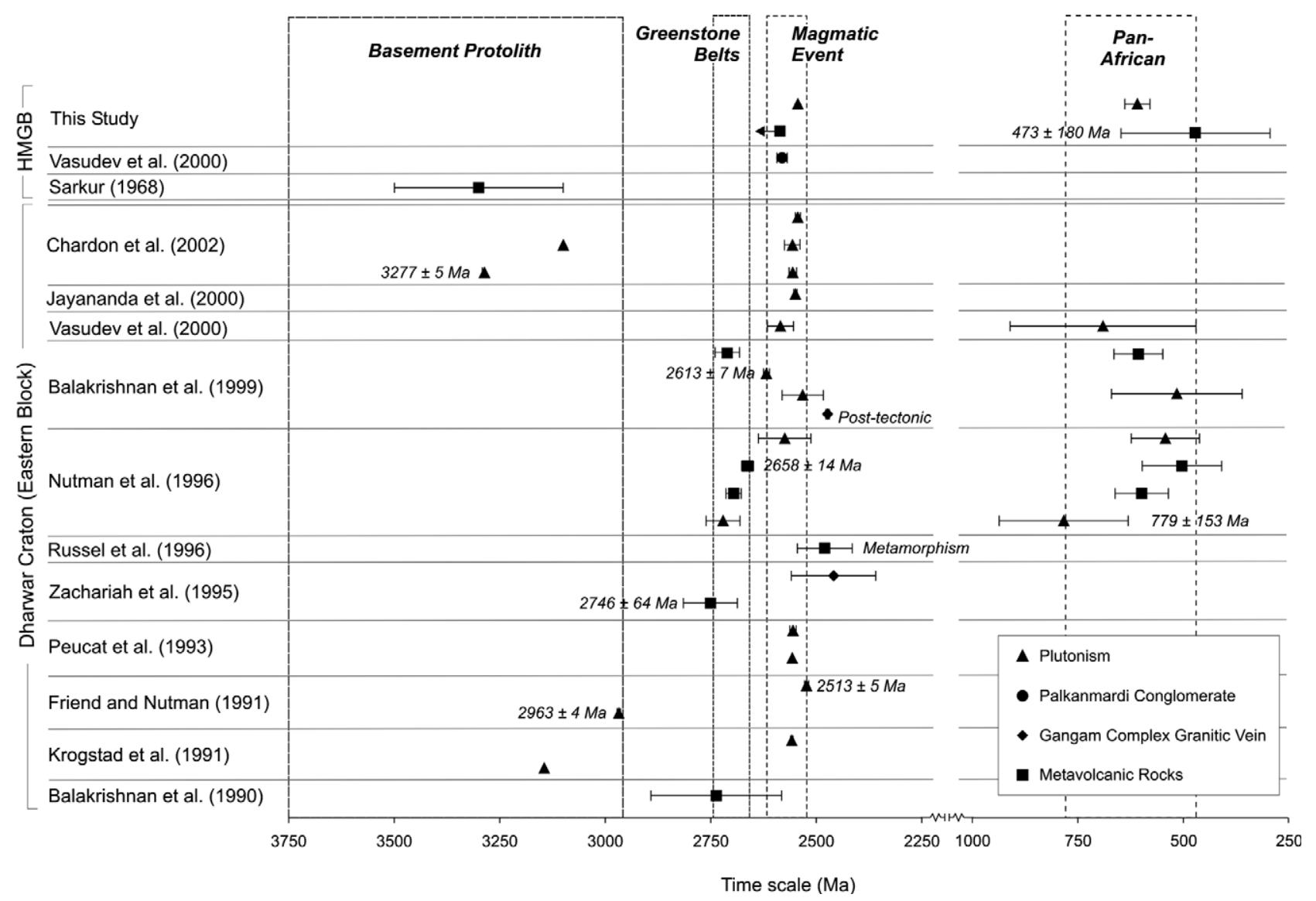

Fig. 12. Geological time scale for the eastern block of the Dharwar Craton, produced from the summarised geochronological data diagrammatically portrayed in Fig. 1. The dashed boxes group individual time periods together, defined by the oldest/youngest ages recorded (the corresponding ages are written where appropriate), see text for discussion. 
Later events include the cross-cutting veinlets $\left(D_{4}\right)$ in the felsic metavolcanic rocks, formed during the Mesoproterozoic (ca. 1180 Ma; Fig. 11a). The lower intercept ages from the felsic metavolcanic rocks and the Uti granodiorite indicate the closure of the $\mathrm{Pb}$ system between 609 and $473 \mathrm{Ma}$ for the HMGB (excluding errors; Fig. 12), presumably related to the Pan-African orogeny. The lower intercept age of the Uti granodiorite at $609 \pm 30 \mathrm{Ma}$ represents the most northerly unit to have been affected by this Neoproterozoic event, previously it was the Sandur Greenstone Belt, which is positioned to the south of the HMGB (Nutman et al., 1996).

\subsection{Dharwar Craton}

The geochronological data summarised in Fig. 1 and displayed in the form of a time line in Fig. 12 can be used to differentiate between individual cratonic events. The age of the basement unit in the eastern block ranges from 3277 to $2963 \mathrm{Ma}$, retrieved from "inherited zircons" as well as the Protolithic Kabbaldurga gneiss (Chardon et al., 2002; Friend and Nutman, 1991; Krogstad et al., 1991; Figs. 1 and 12). The Medinapur gneiss to the west of the HMGB might represent an analogue of this basement. However, without any information from radiometric dating the question whether this lithology represents a $>2.9 \mathrm{Ga}$ basement in the eastern block must remain open.

The ages of the, Kolar, Ramagiri and Sandur Greenstone Belts (2746-2658 Ma excluding errors; Figs. 1 and 12) are in accordance with the minimum age of the HMGB $(2586 \pm 59 \mathrm{Ma})$. Moreover, the tectonic settings for the various Greenstone Belts implies that the eastern block of the craton was an evolving arc-type setting, for Kolar an ocean floor/ island-arc setting (Balakrishnan et al., 1990), for Ramagiri an island-arc setting (Zacharaiah et al., 1995) and for Sandur an intra-arc setting (Hanuma Prasad et al., 1996).

According to the uniformitarian model of Chadwick et al. (2000), the eastern and western blocks of the Dharwar Craton collided, towards the end of the Archean, supported by the setting of the Kolar Greenstone Belt according to Krogstad et al. (1989). Chadwick et al. (1996) attributed the $35 \mathrm{~km}$ thickness of the Sandur Greenstone Belt to thrust stacking, which would have occurred during the collision, also recognised in the Ramagiri Greenstone Belt (Zacharaiah et al., 1996, 1995). In the HMGB, NESW compressional tectonics were also documented (Kolb et al., 2004b), whereas at Kolar intense folding and shearing has obliterated any earlier structures (Hamilton and Hodgson, 1986).

The burial of the Greenstone Belts converted these volcanic sequences in time to amphibolite facies rocks (Hanuma Prasad et al., 1996; Kolb et al., 2005; Zacharaiah et al., 1996). As a consequence of continued accretion the belts were uplifted, the HMGB became cooler and less pressurised, initially to lower amphibolite and finally to lower greenschist facies conditions (Kolb et al., 2005).
The progressive accretion of the Greenstone Belts (arc units) would not have begun before the final episode of volcanic activity ca. 2.6 Ga (2658 \pm 14 Ma Sandur Greenstone Belt, Nutman et al., 1996), which correlates well with the ca. $2.6 \mathrm{Ga}$ age of deformation along the Chitradurga Boundary Shear Zone, which divides the Dharwar Craton, positioned immediately to the west of the Closepet Granite (Fig. 1; Kolb et al., 2004a; Taylor et al., 1984).

The geochronological investigations of the syn- to posttectonic plutonic episodes indicate ca. 100 m.y. of magmatism. The preliminary magmatic activity began at $2613 \pm$ $7 \mathrm{Ma}$ (Central Ramagiri Complex granodiorite, Balakrishnan et al., 1999) and ceased with the intrusion of the Closepet Granite at $2513 \pm 5 \mathrm{Ma}$ (Friend and Nutman, 1991). This final phase of magmatic activity can be correlated with the amalgamation of the craton and cease in tectono-magmatic activity (Drury et al., 1984; Moyen et al., 2003), the suturing of the Kolar Greenstone Belt between 2530 and $2420 \mathrm{Ma}$ (Krogstad et al., 1989) and the post-tectonic granitic vein, which intruded into the Ramagiri Greenstone Belt at $2468 \pm 4 \mathrm{Ma}$ (Balakrishnan et al., 1999; Fig. 12).

The later disturbance of the isotopic system in the Kolar Greenstone Belt around $1100 \mathrm{Ma}$ (Walker et al., 1989), can be correlated with the cross-cutting veinlets in the HMGB ca. $1180 \mathrm{Ma}$. This late fluid may have been associated with the Mesoproterozoic (1000-1400 Ma) Eastern Ghat orogeny, the focal point of which is approximately $200 \mathrm{~km}$ to the east of the HMGB (Divakara Rao et al., 1999). The lower age intersections, from the discordias of the felsic metavolcanic rock and Kavital granitoid also correlate with those published for the eastern block of the craton (Fig. 1). The complete data set indicates the closure of the $\mathrm{Pb}$-system sometime between 779 and $473 \mathrm{Ma}$ (excluding errors), presumably related to the Pan-African orogeny, which characterises the southern region of India approximately $500 \mathrm{~km}$ to the south of the HMGB (Hansen et al., 1985).

\section{Conclusions}

The tectono-magmatic evolution of the Hutti-Maski Greenstone Belt (HMGB) can be established on the basis of detailed, petrology, geochemistry and SHRIMP U/Pb zircon geochronology.

The metavolcanic sequence of the HMGB is typical of non-resurgent, bimodal volcanism, in a primitive arc-type setting. A minimum, magmatic age of $2586 \pm 59 \mathrm{Ma}$ has been recorded in the felsic metavolcanic rocks; this is in accordance with the slightly older ages of the Ramagiri, Kolar and Sandur Greenstone Belts (2746-2658 Ma).

The granitoids associated with the HMGB have an I-Type affinity, tectonically associated with a mature version of the initial primitive-arc most likely in an active subduction zone setting, indicating different stages in the tectonic evolution, from pre- to post-tectonic. The Kavital granitoid is a syn-tectonic, homogeneous, medium-grained porphyritic granodiorite, chemically similar to Archean 
TTG suites with a magmatic age of $2543 \pm 9$ Ma. It was subsequently intruded by the post-tectonic, Yelagatti granitoid, a heterogeneous, fine- to medium-grained granite to granodiorite, dominantly, calc-alkaline, chemically similar to the late Archean granites.

Later events include the formation of veinlets during the Mesoproterozoic (ca. $1180 \mathrm{Ma}$ ) and the closure of the $\mathrm{Pb}$ system between 609 and $473 \mathrm{Ma}$ (excluding errors), which appears to be related to the Pan-African orogeny.

The tectono-magmatic evolution of the HMGB can be correlated with the development and consequently the evolution of the craton, during two distinct events: (1) the collision between the eastern and western blocks of the Dharwar Craton subsequent to $2658 \mathrm{Ma}$, and (2) the craton wide magmatism from 2613 to $2513 \mathrm{Ma}$. These events can be accounted for with the combination of a uniformitarian and non-uniformitarian model (cf. Chadwick et al., 2000; Jayananda et al., 2000).

\section{Acknowledgments}

The authors are thankful for the financial support of the Deutsche Forschungsgemeinschaft Project (Grant $\mathrm{Me}$ 1425/5-1/2). Chemical analyses were carried out at RWTH Aachen University with the advice and guidance of Prof. Dr. W. Plüger. We would also like to thank Ken Ludwig the author of Isoplot and SQUID software packages who helped to interpret the unusual geochronological data set of the Yelagatti granitoid.

\section{References}

Arculus, R.J., Powell, R., 1986. Source component mixing in the regions of arc magma generation. Journal of Geophysical Research 91, 59135926.

Balakrishnan, S., Hanson, G.N., Rajamani, V., 1990. Pb and Nd isotope constraints on the origin of high $\mathrm{Mg}$ and tholeiitic amphibolites, Kolar schist belt, south India. Contributions to Mineralogy and Petrology 107, 279-292.

Balakrishnan, S., Rajamani, V., Hanson, G.N., 1999. U-Pb ages for Zircon and Titanite from the Ramagiri area, southern India: evidence for accretionary origin of the eastern Dharwar Craton during the Late Archean. The Journal of Geology 107, 69-86.

Barker, F., 1979. Trondhjemite: definition, environment and hypothesis of origin. In: Barker, F. (Ed.), Throndhjemites, Dacites and Related Rocks. Elsevier, Amsterdam, pp. 1-12.

Barker, F., Arth, J.G., 1976. Generation of trondhjemitic-tonalitic liquids and Archean bimodal trondhjemitic-basal suites. Geology 4, 596-600.

Barrie, C.T., Shirey, S.B., 1991. Nd and Sr-isotope systematics for the Kamiskotia-Montcalm area: implications for the formation of late Archean crust in the western Abitibi Subprovince, Canada. Precambrian Research 46, 58-76.

Bhaskar Rao, Y.J., Naha, K., Srinivasan, R., Gopalan, K., 1991. Geology, geochemistry and geochronology of the Archaean Peninsular Gneiss around Gorur, Hassan District, Karnataka, India. Proceedings of the Indian Academy of Sciences (Earth and Planetary Sciences) 100 (4), 399-412.

Biswas, S.K., 1990. Gold mineralization in Hutti-Maski Greenstone belt, Karnataka, India. Indian Minerals 44, 1-14.
Biswas, S.K., Parbhakara, K., Rao, P.S., 1985. Preliminary exploration of auriferous lodes of Hutti-Maski schist belt, Karnataka, India, United Nations Inter-regional Seminar on Gold Exploration and Development, Bangalore, pp. 11.2.2.1-11.2.2.29.

Briqueu, L., Bougault, H., Joron, J.-L., 1984. Quantification of Nb, Ta, Ti and $\mathrm{V}$ anomalies in magmas associated with subduction zones: petrogenetic implications. Earth and Planetary Science Letters 68, 297-308.

Brown, G.C., Thorpe, R.S., Webb, P.C., 1984. The geochemical characteristics of granitoids in contrasting arcs and comments on source magmas. Journal of the Geology Society of London 141, 413-426.

Chadwick, B., Vasudev, V.N., Ahmed, N., 1996. The Sandur schist belt and its adjacent plutonic rocks: implications for late Archean crustal evolution in Karnataka. Journal of the Geological Society of India 47, 37-57.

Chadwick, B., Vasudev, V.N., Hedge, G.V., 1997. The Dharwar craton, southern India and its late Archaean plate tectonic setting: current interpretation and controversies. Proceedings of the Indian Academy of Science (Earth and Planetary Science) 106 (4), 1-10.

Chadwick, B., Vasudev, V.N., Hedge, G.V., 2000. The Dharwar craton, southern India, interpreted as the result of Late Archaean oblique convergence. Precambrian Research 99, 91-111.

Champion, D.C., Sheraton, J.W., 1997. Geochemistry and Nd isotope systematics of Archaean granites of the Eastern Goldfields. Yilgarn Craton. Australia: implications for crustal growth processes. Precambrian Research 83, 109-132.

Champion, D.C., Smithies, R.H., 2000. Geochemistry of the Yule Granitoid Complex. East Pilbara Granite-Greenstone Terrane: evidence for early felsic crust. Geological Survey of Western Australia, Annual Review, pp. 42-48.

Chappell, B.J., White, A.J.R., 1974. Two contrasting granite types. Pacific Geology 8, 173-174.

Chardon, D., Peucat, J.-J., Jayananda, M., Choukroune, P., Fanning, C.M., 2002. Archean granite-greenstone tectonics at Kolar (south India): interplay of diapirism and bulk inhomogeneous contraction during juvenile magmatic accretion. Tectonics 21 (3), 1-17.

Claoué-Long, J.C., Compston, W., Roberts, J., Fanning, C.M., 1995. Two carboniferous ages: a comparison of SHRIMP zircon dating with conventional zircon ages and ${ }^{40} \mathrm{Ar} /{ }^{39} \mathrm{Ar}$ analysis. Geochronology Time Scales and Global Stratigraphic Correlation. SEPM Special Publication, pp. 3-21.

Compston, W., Williams, I.M., Myer, C., 1984. U-Pb geochronology of zircons from lunar breccia 73217 using a sensitive high mass-resolution ion microprobe. Journal of Geophysical Research 89B, 525-534.

Divakara Rao, V., Subba Rao, M.V., Murthy, N.N., 1999. Granite forming events and their role in crust formation of the Indian shield. Revista Brasileira de Geociências 29 (1), 33-40.

Drury, S.A., Harris, N.B.W., Holt, R.W., Reeves Smith, G.J., Wightman, R.T., 1984. Precambrian tectonics and crustal evolution in south India. Journal of Geology 92, 3-20.

Fisher, R.V., Schmincke, H.-U., 1984. Pyroclastic Rocks. Springer-Verlag, Berlin, 472 pp.

Friend, C.R.L., Nutman, A.P., 1991. SHRIMP U-Pb geochronology of the Closepet Granite and Peninsular Gneiss, Karnataka, south India. Journal of the Geological Society of India 38, 357-368.

Green, T.H., 1994. Experimental studies of trace-element partitioning applicable to igneous petrogenisis - Sedona 16 years later: chemical. Geology 117, 1-36.

Hamilton, J.V., Hodgson, C.J., 1986. Mineralization and structure of the Kolar Gold Field, India. In: Macdonald, A.J. (Ed.), Proceedings of the Gold' 86 Symposium. International Symposium on the Geology of Gold, Toronto, pp. 270-283.

Hansen, E.C., Hickman, M.H., Grant, N.K., Newton, R.C., 1985. PanAfrican age of 'Peninsular Gneiss' near Madurai, south India. EOS 66, $419-420$.

Hanuma Prasad, M., Krishna Rao, B., Vasudev, V.N., Basavalingu, B., 1996. P-T conditions of metamorphism of supracrustal rocks in the Sandur Schist Belt, Dharwar Craton, southern India. Journal of the Geological Society of India 48, 617-628. 
Hart, S., 1984. A large-scale isotope anomaly in the southern hemisphere mantle. Nature 309, 753-757.

Jayananda, M., Mahabaleshwar, B., 1991. Relationship between shear zones and igneous activity: the Closepet granite of southern India. Proceedings of the Indian Academy of Science (Earth and Planetary Science) $100,31-36$

Jayananda, M. et al., 2000. Late Archaean (2550-2520 Ma) juvenile magmatism in the eastern Dharwar craton, southern India: constraints from geochronology, $\mathrm{Nd}-\mathrm{Sr}$ isotopes and whole rock geochemistry. Precambrian Research 99, 225-254.

Kolb, J. et al., 2004a. The role of a transcrustal shear zone in orogenic gold mineralization at the Ajjanahalli Mine, Dharwar Craton, south India. Economic Geology 99, 743-759.

Kolb, J., Rogers, A., Meyer, F.M., in press. Relative timing of deformation and two-stage gold mineralization at the Hutti Mine, Dharwar craton, India. Mineralium Deposita.

Kolb, J., Rogers, A., Meyer, F.M., Vennemann, T.W., 2004b. Development of fluid conduits in the auriferous shear zones of the Hutti Gold Mine, India: evidence for spatially and temporally heterogeneous fluid flow. Tectonophysics 378, 65-84.

Krogstad, E.J., Balakrishnan, S., Mukhopadhyay, D.K., Rajamani, V., Hanson, G.N., 1989. Plate tectonics 2.5 Billion years ago: evidence at Kolar, south India. Science 243, 1337-1339.

Krogstad, E.J., Hanson, G.N., Rajamani, V., 1991. U-Pb ages of zircon and sphene for two gneiss terranes adjacent to the Kolar schist belt, south India: evidence for separate crustal evolution histories. Journal of Geology 99, 801-816.

Ludwig, K.R., 1999. Isoplot/Ex version 2.00: A Geochronological Toolkit for Microsoft Excel. Berkeley Geochronology Center Special Publication, $46 \mathrm{pp}$.

Ludwig, K.R., 2000. SQUID 1.00, A User's Manual, 2. Berkeley Geochronology Center Special Publication, Berkeley, California, 17 pp.

MacLean, W.H., 1990. Mass change calculations in altered rock series. Mineralium Deposita 25, 44-49.

Manikyamba, C., Naqvi, S.M., Ram Mohan, M., Gnaneshwar Rao, T., 2004. Gold mineralisation and alteration of Penakacherla schist belt, India, constraints on Archaean subduction and fluid processes. Ore Geology Reviews 24, 199-227.

Martin, H., 1994. The Archean grey gneisses and the genesis of the continental crust. In: Condie, K.C. (Ed.), The Archean Crustal Evolution. Elsevier, Amsterdam, Lausanne, New York, pp. 205-260.

Moyen, J.F., Nédélec, A., Martin, H., Jayananda, M., 2003. Syntectonic granite emplacement at different structural levels: the Closepet granite, south India. Journal of Structural Geology 25, 611-631.

Nutman, A.P., Chadwick, B., Krishna Rao, B., Vasudev, V.N., 1996. SHRIMP U/Pb zircon ages of acid volcanic rocks in the Chitradurga and Sandur groups, and granites adjacent to the Sandur Schist Belt, Karnataka. Journal of the Geological Society of India 47 (2), 153-164.

Paces, J.B., Miller, J.D., 1989. Precise U-Pb ages of Duluth complex and related mafic intrusions, northeastern Minnesota: geochronological insights to physical, petrogenic, paleomagnetic and tectonomagmatic processes associated with the $1.1 \mathrm{Ga}$ midcontinent rift system. Journal of Geophysical Research 98B, 13997-14013.

Pearce, J.A., 1982. Trace element characteristics of lavas from destructive plate boundaries. In: Thorpe, R.S. (Ed.), Andesites. Wiley, Chichester, pp. 525-548.

Pearce, J.A., 1983. Role of the sub-continental lithosphere in magma genesis at active continental margins. In: Hawkesworth, C.J., Norry, M.J. (Eds.), Continental Basalts and Mantle Xenoliths. Shiva, Nantwich, pp. 230-249.

Peucat, J.J., Mahabaleshwar, B., Jayananda, M., 1993. Age of younger tonalitic magmatism and granulitic metamorphism in the south India transition zone (Krishnagiri area): comparison with older Peninsular gneisses from the Gorur-Hassan area. Journal of Metamorphic Geology 11, 879-888.

Radhakrishna, B.P., 1983. Archaean granite-greenstone terrain of the south Indian shield. In: Naqvi, S.M., Rogers, J.J.W. (Eds.),
Precambrian of South India. Geological Society of India, Memoirs, pp. 1-46.

Radhakrishna, B.P., Vasudev, V.N., 1977. The early Precambrian of the southern Indian shield. Journal of the Geological Society of India 18, $525-541$.

Rajamani, V., Shivkumar, G.N., Hanson, G.N., Shirey, S.B., 1985. Geochemistry and petrogenesis of amphibolites, Kolar schist belt, south India: evidence for komatitic magma derived by low percentages of melting of the mantle. Journal of Petrology 26 (1), 92-123.

Raju, K.K., Sharma, J.P., 1991. Geology of mineralisation of the Hutti gold deposit, Karanataka. In: Proceedings of the Symposium Brazil Gold '91, Brazil, pp. 469-477.

Ramakrishnan, M., Viswanatha, M.N., Swami Nath, J., 1976. Basementcover relationship of Peninsular gneisses with high grade schists and greenstone belts of southern Karnataka. Journal of the Geological Society of India 17, 97-111.

Roddick, J.C., van Breemen, O., 1994. U-Pb zircon dating: a comparison of ion microprobe and single grain conventional analyses. Radiogenic Age and Isotopic Studies: Report 8. Geological Survey of Canada, 1994-F, 1-9.

Rollinson, H.R., 1993. Using geochemical data: evaluation, presentation, interpretation. Geochemistry Series. Longman Scientific \& Technical, Essex, 352 pp.

Roy, A., 1979. Polyphase folding deformation in the Hutti-Maski schist belt, Karnataka. Journal of the Geological Society of India 20, 598607

Roy, A., Biswas, S.K., 1982. A note on the "volcanic conglomerate"/ pyroclast horizon near Palkanmaradi in the Hutti schist belt, Karnataka. Journal of the Geological Society of India 23, 506510.

Russell, J., Chadwick, B., Krishna Rao, B., Vasudev, V.N., 1996. Wholerock $\mathrm{Pb} / \mathrm{Pb}$ isotopic ages of Late Archean limestones, Karnataka, India. Precambrian Research, 78, 261-272.

Sarkar, S.N., 1968. Precambrian Stratigraphy and Geochemistry of Peninsular India. Dhanbad Publishers, Dhanbad (India), 33 pp.

Shand, S.J., 1927. Eruptive Rocks. Wiley, New York.

Sisson, T.W., 1994. Hornblende-melt trace-element partitioning measured by ion microprobe. Chemical Geology 117, 331-344.

Smeeth, W.F., 1915. Geological Map of Mysore. Department of Mines and Geology, Mysore.

Srikantia, S.V., 1995. Geology of the Hutti-Maski greenstone belt. In: Curtis, L.C., Radhakrishna, B.P. (Eds.), Hutti Gold Mine into the 21st Century. Geological Society of India, pp. 8-27.

Sun, S.S., McDonough, W.F., 1989. Chemical and isotopic systematics of oceanic basalts: implications for mantle composition and processes. In: Saunders, A.D., Norry, M.J. (Eds.), Magmatism in the Ocean Basins. Geological Society Special Publication, pp. 313-345.

Swaminath, J., Ramakrishnan, M., 1981. Early Precambrian supracrustals of southern Karnataka (A) present classification and correlation. Memoirs Geological Survey of India 112, 23-38.

Sylvester, P.J., 1994. Archean granite plutons. In: Condie, K.C. (Ed.), The Archean Crustal Evolution. Elsevier, Amsterdam, Lausanne, New York, pp. 261-314.

Taylor, P.N., Chadwick, B., Moorbath, S., Ramakrishnan, M., Viswanathan, M.N., 1984. Petrography, chemistry and isotopic ages of Peninsular gneiss, Dharwar acid volcanic rocks and Chitradurga granite with special reference to the Archaean evolution of the Karnataka craton. Precambrian Research 23, 349-379.

Taylor, S.R., McLennan, S.M., 1985. The Continental Crust: Its Composition and Evolution. Blackwell Scientific Publications, Oxford, 312 pp.

Thurston, P.C., 1994. Archean volcanic patterns. In: Condie, K.C. (Ed.), Archean Crustal Evolution. Developments in Precambrian Geology. Elsevier, Amsterdam, Lausanne. New York, pp. 45-84.

Vasudev, V.N., Chadwick, B., Nutman, A.P., Hedge, G.V., 2000. Rapid development of the Late Archaean Hutti schist belt, northern Karnataka: Implications of new field data and SHRIMP U/Pb zircon ages. Journal of the Geological Society of India 55, 529-540. 
Walker, R.J., Shirey, S.B., Hanson, G.N., Rajamani, V., Horan, M.F., 1989. Re-Os, Rb-Sr and O isotopic systematics of the Archean Kolar schist belt, Karnataka, India. Geochimica et Cosmochimica Acta 53, 3005-3013.

Williams, I.S., 1998. U-Th-Pb geochronology by ion microprobe. In: McKibben, M.A., Shanks, W.C., IIIIII, Ridley, W.I. (Eds.), Applications of Microanalytical Techniques to Understanding Mineralizing Processes. Reviews in Economic Geology, pp. 1-35.
Zacharaiah, J.K., Hanson, G.N., Rajamani, V., 1995. Post-crystallization disturbance in the neodymium and lead isotope systems of METABASALTS from the Ramagiri schist belt, southern India. Geochimica et Cosmochimica Acta 59, 3189-3203.

Zacharaiah, J.K., Hanson, G.N., Rajamani, V., 1996. Accretionary evolution of the Ramagiri schist belt, eastern Dharwar craton. Journal of the Geological Society of India 47, 279291. 